NBER WORKING PAPER SERIES

\title{
THE IMPACT OF WAR ON RESOURCE ALLOCATION: 'CREATIVE DESTRUCTION' AND THE AMERICAN CIVIL WAR
}

\author{
B. Zorina Khan \\ Working Paper 20944 \\ http://www.nber.org/papers/w20944
NATIONAL BUREAU OF ECONOMIC RESEARCH
1050 Massachusetts Avenue
Cambridge, MA 02138
February 2015

I benefited from comments and discussions with Stanley Engerman, Joseph Ferrie, Claudia Goldin, Naomi Lamoreaux, Robert Margo, Joel Mokyr, Jean-Laurent Rosenthal, Ross Thomson and Mark Russell Wilson. I received helpful suggestions from participants in seminars at Rutgers University, Harvard University, the American Economic Association, the Economic History Association meeting, and the National Bureau of Economic Research. Caroline Quinn and Jonathan Crowley provided efficient research assistance. The National Science Foundation provided funding in part for this project. I am also grateful for general support from the National Fellows Program and the IP2 Working Group at the Hoover Institution, Stanford University. Liability for errors is limited to the author. The views expressed herein are those of the author and do not necessarily reflect the views of the National Bureau of Economic Research.

NBER working papers are circulated for discussion and comment purposes. They have not been peerreviewed or been subject to the review by the NBER Board of Directors that accompanies official NBER publications.

(C) 2015 by B. Zorina Khan. All rights reserved. Short sections of text, not to exceed two paragraphs, may be quoted without explicit permission provided that full credit, including $\odot$ notice, is given to the source. 
The Impact of War on Resource Allocation: 'Creative Destruction' and the American Civil

War

B. Zorina Khan

NBER Working Paper No. 20944

February 2015

JEL No. N11,N4,O3,O51

\begin{abstract}
What is the effect of wars on industrialization, technology and commercial activity? In economic terms, such events as wars comprise a large exogenous shock to labor and capital markets, aggregate demand, the distribution of expenditures, and the rate and direction of technological innovation. In addition, if private individuals are extremely responsive to changes in incentives, wars can effect substantial changes in the allocation of resources, even within a decentralized structure with little federal control and a low rate of labor participation in the military. This paper examines war-time resource reallocation in terms of occupation, geographical mobility, and the commercialization of inventions during the American Civil War. The empirical evidence shows the war resulted in a significant temporary misallocation of resources, by reducing geographical mobility, and by creating incentives for individuals with high opportunity cost to switch into the market for military technologies, while decreasing financial returns to inventors. However, the end of armed conflict led to a rapid period of catching up, suggesting that the war did not lead to a permanent misallocation of inputs, and did not long inhibit the capacity for future technological progress.
\end{abstract}

B. Zorina Khan

9700 College Station

Bowdoin College

Brunswick, ME 04011

and NBER

bkhan@bowdoin.edu 


\section{INTRODUCTION}

"War among civilized peoples, equal in number, is a contest of Science and Wealth"

--New York Times (1862) ${ }^{1}$

The relationship between war and technology has long attracted scholarly attention, with a division among those who argue that armed conflicts boosts economic activity and the opposing view that wars lead to a deleterious effect. Indeed, the concept of "creative destruction" originated with Werner Sombart, who provided the classic exposition of the argument that wars have a positive impact on industrialization and technological change. ${ }^{2}$ Later on, Charles and Mary Beard would present a version of this thesis when they argued that the American Civil War promoted the economic prosperity of the Northern economy. ${ }^{3}$ More recently, the "triumph of the West" has been attributed to its aggressive and technologically innovative military traditions. ${ }^{4}$ By contrast, John U. Nef proposed that wars had negative consequences that extended beyond the obvious costs of mortality and injuries, or the opportunity cost of mobilization of labour and other resources into the military. Nef highlighted the impact on invention and innovation: wartime technologies were merely based on already existing ideas, diverted the attention of inventors and innovators from more productive endeavours, and even had the capacity to destroy the potential for inventiveness, new ideas and progress. ${ }^{5}$ Despite the plethora of research, significant aspects of this issue have not been subjected to empirical assessment, and the key contentions remain unresolved.

\footnotetext{
${ }^{1}$ According to the New York Times, Feb 17, 1862, p. 4, “The iron gunboats are merely an exponent of those qualities which have gained the victory - the ingenuity, mechanical skill, perseverance and calm courage of a Northern free people ... For it must be remembered that in modern days the great difference between the armies of civilized nations is not so much in personal courage as in equipment and discipline.... War among civilized peoples, equal in number, is a contest of Science and Wealth. Such a people as ours... Their invention is incessantly at work; the genius which has won such successes in the arts of peace is now applied constantly to the formation of implements of destruction, or to the combinations of strategy... new weapons will be invented, and all the energy of our untiring and ingenious national improvement will be turned to the shortest, and most terrible methods of destruction.”

${ }^{2}$ Sombart's opus, Krieg Und Capitalismus, remains untranslated into English. For an explication of his views, see Waldemar Kaempffert, "War and Technology,” American Journal of Sociology, vol. 46 (4) 1941: 431-444. Kaempffert declares (p. 432) that the discovery of gunpowder "did quite as much as the invention of movable types and the steam engine to change the structure of society ... and to lay the foundations of engineering and mass production."

${ }^{3}$ Charles Beard and Mary Beard, The Rise of American Civilization, New York: Macmillan, 1927.

${ }^{4}$ Geoffrey Parker (ed), The Cambridge Illustrated History of Warfare: the Triumph of the West, Cambridge: Cambridge University Press, 1995.

${ }^{5}$ John U. Nef, War and Human Progress: An Essay on the Rise of Industrial Civilization, Cambridge: Harvard University Press, 1950.
} 
The American Civil War is widely regarded as a watershed in military technique and technology, characterized by a transition from the (literally) more regimented European precedent toward modern strategies that placed a premium on the tools of warfare. ${ }^{6}$ The Civil War heralded the advent of a more capital-intensive approach to armed conflict, and the quest for superior innovations that could transform untutored recruits into formidable adversaries. ${ }^{7}$

Historians have produced extensive case studies of specific technologies and innovations that were introduced during the war. ${ }^{8}$ Economists, on the other hand, have paid little attention to wartime technology and have instead investigated such issues as the direct and opportunity costs of the war, the efficacy of naval blockades, the experience of veterans, and links to financial markets. ${ }^{9} \quad$ It is somewhat surprising that, amidst the vast array of books and articles on the Civil War, none provides a systematic analysis of technological change during this period. After all, few would question that, in the "Republic of Technology" that flourished during the

\footnotetext{
${ }^{6}$ The Confederacy was especially unprepared for the advent of modern warfare. Josiah Gorgas, the Confederate Chief of Ordnance notes that, “in the winter of 1861-'62, while McClellan was preparing his great army near Alexandria, we resorted to the making of pikes for the infantry and lances for the cavalry; many thousands of the former were made at the various arsenals, but were little used. No access of enthusiasm could induce our people to rush to the field armed with pikes.” [From an 1895 article by Gorgas, reprinted in Fuller and Steuart, Firearms of the Confederacy, p. 117.] See also Frank E. Vandiver, Ploughshares into Swords: Josiah Gorgas and Confederate Ordnance, Austin: University of Texas Press, 1952.

7 The famous patentee John Ericsson advised Abraham Lincoln that "The time has come, Mr. President, when our cause will have to be sustained, not by numbers, but by superior weapons. By a proper application of mechanical devices alone will you be able with absolute certainty to destroy the enemies of the Union ... if you apply our mechanical resources to the fullest extent, you can destroy the enemy without enlisting another man" cited p. 68, Robert V. Bruce, Lincoln and the Tools of War, Indianapolis: Bobbs-Merrill Co., 1956. Ericsson designed the ironclad Monitor which was involved in the encounter with the Merrimac early in 1862. The Monitor incorporated the patented inventions of other inventors, such as Theodore Timby's revolving gun turrets.

8 These included improvements in repeating firearms, breech-loading rifles, explosives, hand-grenades and underwater torpedoes, aeronautics and aerial reconnaissance, pontoon bridges, ironclad battleships, manned submarines, trench warfare, and the military use of telegraphy and rail transportation. For an excellent survey of the historiography, see Alex Roland, “Technology and War: A Bibiographic Essay,” in Merritt Roe Smith (ed), Military Enterprise and Technological Change, Cambridge: MIT Press, 1985, pp. 347-379.

${ }^{9}$ A small sample of such work includes Ralph Andreano (ed), The Economic Impact of the American Civil War, Cambridge: Schenkman, 1962; Stanley L. Engerman, “The Economic Impact of the Civil War,” Explorations in Entrepreneurial History, vol. 3 , Spring/Summer, (1966): 176-199; Claudia D. Goldin and Frank D. Lewis, "The Economic Costs of the American Civil War: Estimates and Implications,” Journal of Economic History, vol. 35 (June) 1975: 299-325; David T. Gilchrist and W. David Lewis (eds), Economic Change in the Civil War Era, Greenville: Eleutheran Mills-Hagley Foundation, 1965; Patrick O’Brien, The Economic Effects of the American Civil War, London: 1988. Classic economic history studies of European wars and technology include Carlo Cippola, Guns, Sails and Empires: Technological Innovation and the Early Phases of European Expansion, 1400$\underline{1700}$, which attributes European dominance to its command of superior military technologies, and David S. Landes, The Unbound Prometheus: Technological Change and Industrial Development in Western Europe from 1750 to the Present Day. See also William H. McNeill, The Pursuit of Power: Technology, Armed Force, and Society since A.D. 1000, which highlights the way in which technology and the state combine to create centralized power, and Clive Trebilcock, “'Spin-off in British Economic History: Armaments and Industry, 1760-1914,” Economic History Review vol. 22 (December) 1969: 474-490.
} 
nineteenth century, Americans approached militarization in the same spirit as they did industrialization. $^{10}$

In economic terms the Civil War comprised a large exogenous shock in American society that affected labour and capital markets, aggregate demand, the distribution of expenditures and national income. In addition to these macroeconomic factors, however, the war altered the existing opportunity set and created incentives for entrepreneurial individuals to alter their behaviour to take advantage of the potential for supranormal returns. Such indirect microeconomic effects of large-scale armed conflict are not simple to measure or interpret, but they warrant examination if we are to better understand the more subtle costs or consequences of wars. For instance, some scholars have approached the study of war in terms of its "totality," defined as the degree of centralization, mobilization and federal control. ${ }^{11}$ Yet, such organizational factors are neither necessary nor sufficient for a broad society-wide impact of war: if private individuals were extremely responsive to changes in incentives, wars could bring about substantial changes in the allocation of resources even within a decentralized structure with little federal control and low labour participation in the military. ${ }^{12}$

The existing body of research leaves many questions unexplored. How did the war affect patterns of patenting and comparative advantage in inventive activity across regions? Who were the individuals who were taking advantage of the opportunities that the American Civil War created, and how typical were they? Were contributions to the war primarily made by entrepreneurial individuals who radically changed their orientation, or did the major response

\footnotetext{
${ }^{10}$ Indeed, one of the first acts of the Confederate Congress was to introduce a patent system. Scientific American, $\mathrm{v}$ 4 (ns) no 20, p 307, 18 May 1861 reported that Jefferson Davis notified the Congress of the Confederate States on the $29^{\text {th }}$ of April that "I refer you to the report of the Attorney General, and concur in his recommendation for immediate legislation, especially on the subject of patent rights... The Patent Office Business is much more extensive and important than had been anticipated. The applications for patents, although confined under the law exclusively to citizens of our confederacy, already average seventy per month, showing the necessity for the prompt organization of a bureau of patents." Scientific American, however, was dismissive of the notion that "inventive talent has suddenly sprung up among the Southern people." The analogue of the "intellectual property clause" of the U.S. Constitution appears as Art. 1, Sec. 6, Cl. 8 of the Confederate Constitution: "To promote the progress of science and useful arts, by securing for limited times to authors and inventors the exclusive right to their respective writings and discoveries.”

${ }^{11}$ Stig Förster and Jörg Nagler (eds), On the road to total war : the American Civil War and the German Wars of Unification, 1861-1871, Washington, D.C. : German Historical Institute ; Cambridge [England] ; New York : Cambridge University Press, 1997. Stanley Engerman and Matthew Gallman's article in this volume defines total war in terms of the degree of economic mobilization of the population for war and the amount of centralized direction imposed by the state, and by this measure find that the claim for total war was greater in the South relative to the North. "[The North] did not embark upon total war because it did not have to. The South, on the other hand, moved toward total war because it had to" (p. 247).

${ }^{12}$ Indeed, the French version of Nef's opus was titled "the road to total war." John U. Nef, La Route de la Guerre Totale, Paris: Librairie Armand Colin, 1949.
} 
emanate from those who were already specialized in weaponry in the antebellum period? As John Nef pointed out, it is important to consider whether wars created new technologies or simply diverted existing inventive resources into the military sector. Arguably, the former (technological creation) will tend to have greater reallocative effects relative to the latter (technological diversion.) Finally, it is relevant to link a military orientation to the question of the returns to entrepreneurial activities. This would require exploring whether there were disproportionate changes in the wealth of war-responsive inventors relative to general inventors or to the overall population.

This paper examines such issues to shed more light on the relationship between war and technology. The analysis is based on patents filed between 1855 and 1870, as well as a sample of individuals who contributed to inventive activity during this period. The first section of the paper examines patterns of patenting in the nineteenth century and during the Civil War era in particular. The second section assesses the characteristics of inventors, and considers entrepreneurial behaviour in terms of responsiveness to war needs. Resource reallocation is discussed in terms of occupational change, geographical mobility, and commercialization during the war. The focus is on patentees who first entered the market for invention during the Civil War, and those who filed their first military invention during this period. The final section assesses the return to entrepreneurship in terms of the individual's responsiveness to the war and offers a brief conclusion.

\section{PATENTING IN THE CIVIL WAR}

“Rouse your inventive faculties...'Necessity is the parent of invention;' and how can you display your patriotism to better purpose, if not fighting, than by contriving...to meet the demands of the nation"

--Richmond Examiner (1861)

The U.S. Constitution was the first such document in history to incorporate a specific clause to protect the discoveries of inventors, and the patent system it authorized was widely acknowledged to be the most successful of the nineteenth century. Secure property rights, an efficient legal system, effective mechanisms for the diffusion of information, and transparent rules and standards created an environment that was extremely favourable to investments in inventive activity. Thus, when improvements in transportation networks and increases in national output brought about market expansion and the prospect of higher expected returns, 
patenting surged in the antebellum period. Patentees in general tended to be located in commercialized urban and metropolitan areas, but residents in rural locations were attracted into inventive activity when formerly isolated areas were integrated into the regional economy. ${ }^{13}$ These new entrants tended to be quite ordinary individuals who changed their focus in order to take advantage of the potential profit opportunities that improved access to markets offered. ${ }^{14}$ Research on "great inventors" showed that these features of the patenting record were not limited to trivial improvements, but also applied to technologically and economically important inventions. The majority of the great inventors exhibited a high propensity to patent their discoveries, and inventors from humble backgrounds benefited disproportionately from the security that such property rights offered. Well-enforced patent rights increased the effectiveness of markets in invention by creating tradable assets that helped relatively disadvantaged inventors to appropriate returns by selling off their rights rather than depending on the ability to raise capital from personal sources or through financial markets. ${ }^{15}$

Some might question the focus on patenting but there is ample evidence that inventors during the $19^{\text {th }}$ century were especially anxious to secure their rights through patenting. ${ }^{16}$ Patent rights might have been even more valuable during the war, because patent portfolios could serve as a signal of reputation and reliability that gave an advantage to bidders for military contracts. For example, the Surgeon General in 1866 furnished a list of approved suppliers of prosthetic devices that the federal government funded, and over 80 percent of them had previously taken

\footnotetext{
${ }^{13}$ For evidence on the responsiveness of antebellum inventors to changes in market demand, see Kenneth L. Sokoloff, "Inventive Activity in Early Industrial America: Evidence from Patent Records, 1790-1846," Journal of Economic History, vol. 48 (4) 1988: 813-850.

${ }^{14}$ See Kenneth L. Sokoloff and B. Zorina Khan, “The Democratization of Invention,” JEH vol. 50 (2)1990: 363378.

${ }^{15}$ See B. Zorina Khan and Kenneth L. Sokoloff, "Institutions and Technological Innovation During Early Economic Growth: Evidence from the Great Inventors of the United States, 1790-1930,” in Institutions and Economic Growth, (eds) Theo Eicher and Cecilia Garcia-Penalosa, MIT Press (2006):123-158.

${ }^{16}$ It is not coincidental that President Abraham Lincoln was a patentee and former patent lawyer; his Secretary of War a patent lawyer; his Secretary of the Treasury a Patent Office Commissioner; and his Chiefs of Navy Ordnance and Military Engineering were both eminent inventors. President Lincoln's State of the Union address in 1861 after the outbreak of the war mentioned the condition of the Patent Office and, even with all the pressures of a bitter and divisive conflict, he was daily involved in personal communications with inventors and in tests of their military innovations. (For Lincoln's interactions with hopeful military inventors, see Robert V. Bruce, Lincoln and the Tools of War, University of Illinois Press, 1989, who notes that "the secretaries gave Lincoln at least three times as large a proportion of inventors' letters as they did of other kinds" (p. 77).) Lincoln approved the founding of the National Academy of Science in 1863 in part to provide the federal government with ready access to new discoveries. Congress concerned itself as late as March 1861 with patent business, producing the second major overhaul of the law in the century. The propensity to patent in terms of patents filed per domestic resident was significantly higher during the nineteenth century than during the past three decades. This might be due to the nature of technology, which at the time was fairly easy to duplicate; to the industrial composition; differences in the organization of firms; or to greater imperfection in capital markets.
} 
out patents on these products. ${ }^{17}$ Patents were also beneficial because they differentiated products, at a time when poor quality in such equipment as artillery or explosives could result in large negative externalities. Thus, it seems plausible that changes in the patterns of patenting during this period were representative of inventive activity in general, and of military inventions in particular.

Nef had argued that wars tend to retard inventive activity and, at the most aggregate level, the data support this contention. On the eve of the Civil War the United States was poised for rapid growth in innovation and industrialization. Patenting was increasing at an annual average rate of 19 percent, well in excess of population growth. As Figure 1 shows, the immediate effect of the onset of hostility was a fall in patent grants from 4363 in 1860, to 3040 in 1861, and 3781 in $1863 .{ }^{18}$ Patenting recovered somewhat in the following two years, and jumped significantly at the end of the war, with over 12300 patents recorded in 1867 . Table 1 presents information on broad geographic patterns of patenting before, during, and after the war. What stands out from the table is that the war did not significantly alter regional comparative advantages, and per capita patenting was notably resilient in all localities. As might be expected, the South and the Confederate states experienced a sharp decline in their patenting during the war, which was not compensated for by their filings in the Confederate Patent Office. There was some variation across states in terms of relative positions between 1861 and 1865: for instance Pennsylvania lost ground, and New York increased its share somewhat. The share of patents in frontier regions in the Midwest and West increased, and patenting in Illinois in particular grew from 3 percent to almost 7 percent. However, these patterns are not inconsistent with the trends in technological change during the entire nineteenth century. The tremendous surge in all areas of patenting immediately after the war suggests that the conflict simply have delayed the timing of when some new technologies emerged.

\footnotetext{
${ }^{17}$ See the report of Edwin Stanton, "Artificial Limbs Furnished to Soldiers," $39^{\text {th }}$ Congress, $1^{\text {st }}$ Session, Ex. Doc. No. 108, House of Representatives. As of May 11 1866, the government had provided prosthetics for 6075 amputees, at a cost of $\$ 357,728$. An article about one of the approved suppliers, the Salem Leg Company, notes that "This company is, we understand, regularly organized and in possession of all the patents of the inventor. So marked is the superiority of the 'Salem Leg' over all other inventions, that the company can have no lack of orders, especially from those who have suffered amputation in the army, as this invention has the sanction and recommendation of the government, which pays the expense of furnishing the limbs.” South Danvers Wizard, 6/1/1864, p. $2 / 4$.

${ }_{18}$ The decrease was not due to a lag in processing applications: the patent application series follows the patents granted closely. During the Civil War period 63 percent of all patent applications were granted, which is approximately the same as the 62 percent average for the period between 1860 and 1880 . Between 1861 and 1865 20, 779 patents were granted out of 33, 291 applications.
} 
Within the general stagnation in total patents, inventors responded disproportionately to the stimulus that the war provided. Changes in sectoral composition were minor, but there was a sharp and marked increase in military inventions. ${ }^{19}$ At the start of the war the "belligerent arts" were somewhat underdeveloped, and combatants were provided with muzzle-loading muskets, paper cartridges that dissolved in the rain, cannon that exploded after several rounds, projectiles that were unpredictable in their trajectory, firearms with minimal range and accuracy, and fuzes that were unreliable. Inventors quickly turned their attention to remedying these routine defects. Patents for improvements to cannon, projectiles, small arms, cartridges and tents increased from 128 in 1860, to 345 in 1862, and 403 in the following year. However, the greatest relative increase was in improvements to small arms and their cartridges, which promised the largest market. As the Commissioner of Patents noted, "whatever improvements tend to the perfecting of the weapons of the private soldier must have a great value in warfare, where, as is usually the case, masses of men are marshaled to oppose collected masses. „20

Figure 2 presents a time series of the ratio of weaponry to total patents filed between 1790 and 2000. The results are striking, since this proportion was twice as high during the Civil War relative to the First and Second World Wars. ${ }^{21}$ Patentees were responsive to other dimensions of conflict besides the need for overt military technologies, and a significant number turned their attention to war-related inventions, including improvements in knapsacks, tents, groundsheets, ambulances, and military flares. ${ }^{22}$ Prosthetics comprised an especially poignant category of war-related inventions that demonstrate the sensitivity of inventors to potential returns. Figure 3 shows the pattern for prosthetic inventions, which jumped from 25 in the previous decade, to 104 during the 1860s. The Commissioner of Patents, T. C. Theaker, in his

\footnotetext{
${ }^{19}$ The share of agriculture fell by 5 percent and manufacturing increased by 7 percent. The New York Times of Dec 6, 1861, p. 4 reported that "...the war has so stimulated the inventive Yankee brain that the Office at Washington fairly groans (we believe that is the figure) under the weight of instruments of destruction, and Gen. McClellan has but to adopt any one out of ten thousand patent kill-alls to utterly annihilate the rebels' "grand army of the Potomac.””

${ }^{20}$ The quotation and the data are from the Annual Report of the Commissioner of Patents for 1863, Washington, DC: Govt Printing Office, 1864.

${ }^{21}$ Weaponry is defined as patents that fall within patent classes 42 (firearms); 86, 102 and 149 (ammunition and explosives); 89 (ordnance); and 124 (mechanical guns). The size of the wartime effect during the nineteenth century relative to the twentieth century might be due to greater responsiveness among $19^{\text {th }}$ century inventors, but it could also owe to the more diffuse nature of military technologies during the twentieth century.

${ }^{22}$ For instance, William B. Johns, an army captain from Georgetown, D.C., obtained patents in 1861 for saddle leggings "very well adapted to army use, not only for mounted officers, but for general cavalry use;" and an "improved military equipment" invention that could be converted from a sheet into a knapsack, tent, or military cloak; as well as a patent for portable fireplaces that "thus take up but little of the most valuable room, while the property of retaining the heat thus gained renders it peculiarly desirable for keeping the tent comfortable during the great part of cold nights, so that it thereby becomes very useful for an army in winter quarters."
} 
Annual Report for 1865 recorded a fall off in "warlike implements," but noted that "the havoc of war has begotten a multitude of inventions to supply the place of amputated arms and legs, and from among the mass some may be selected as examples of skill and successful operation.” During the Civil War anaesthetics were applied to great effect, there were higher survival rates among the wounded, and this meant that a large number of soldiers who suffered amputations required artificial limbs. ${ }^{23}$ Patents for improvements in prosthetics declined toward the end of the war, then grew rapidly after Congress decided in 1866 and 1870 to continue to underwrite the costs of artificial limbs that were provided to disabled soldiers.

\section{ENTREPRENEURSHIP AND INVENTION AMONG PATENTEES}

"The inventive genius of the nation within the last few years had taken a direction which has prepared the nation for the enormous demands upon her"

--Commissioner of Patents (1863)

Some of the inventors who filed patents for military inventions during the Civil may have had purely patriotic motives but many were attempting to exploit potential profit opportunities. The experience of inventors of weaponry and war-related patents, when compared to the white male population and to patentees of general inventions, may yield insights into the relationship between war and technology. This section first examines the characteristics that were associated with a military orientation among inventors, including career patterns and commitment to patenting. Moreover, it allows us to gauge the effects of the war on such forms of resource reallocation as changes in location and occupation, by considering how occupational and geographical mobility before and after the war differed for those with more inventive capital relative to the general population.

The analysis is based on a stratified random sample of 1359 inventors who filed at least one patent between 1855 and $1870 .{ }^{24}$ These included 720 patentees of general inventions; and 639 military inventors. Two hundred and fifty five of the patentees were filed patents in the period from 1855 to the Civil War; 673 from the Civil War period; and 431 from the post bellum

\footnotetext{
${ }^{23}$ About 20,559 or 8.1 percent of all wounded Civil War soldiers underwent amputation, the incidence of which was higher during the Civil War because of the increased range of rifles and artillery. Robert H. Meier, in Robert H. Meier and Diane J. Atkins (eds), Functional Restoration of Adults and Children with Upper Extremity Amputations, New York: Demos Medical Publishing, 2004. See Susan Provost Beller, Medical practices in the civil war, Cincinnati, Ohio: Betterway Books, 1992; and Katherine Ott, David Serlin, and Stephen Mihm (eds), Artificial Parts, Practical Lives: Modern Histories of Prosthetics, New York: NYU Press, 2002.

${ }^{24}$ Southerners are over-sampled because I attempted to trace the inventors of all 269 patents that were filed in the Confederate Patent Office during its term of existence. For further information on the sample, see the notes to Table 2.
} 
period through 1870. I catalogued the full patenting record over the patentee's lifetime, amounting to a total of 8542 patents for all inventors. The patentees were matched across both manuscript censuses in 1860 and 1870 in order to capture changes that occurred in their individual circumstances before and after the war. The linkage to manuscript censuses yielded information on age, place of birth, residence, migration, occupations, real estate wealth, personal wealth, and military status (whether the inventor was a veteran). The control sample consists of 1712 white native-born males drawn from the Integrated Public Use MicroData census, and traced between 1860 and $1870 .^{25}$

During the war both ordinary and "great inventors" dramatically changed the rate and direction of their activities toward military technologies, and toward other areas where markets were expanding, such as in the demand for cotton substitutes. ${ }^{26}$ Table 2 provides more information on the occupational distributions of inventors before and after the war. As might be expected, a number of the inventors of weaponry and war-related devices were eminent military men, such as Henry M. Naglee, a West Point graduate and Brigadier-General in the Union Army, who in 1863 devised an apparatus for locating and exploding submarine torpedoes. Others were less distinguished veterans, such as John Oliphant, an ordinary labourer from Uniontown, Pennsylvania, who filed a patent in January 1863 for a safety catch for firearms. ${ }^{27}$ However, inventors tended for the most part to be untechnical artisans, farmers, labourers and professionals. Although farmers accounted for the single largest occupational category in the general population, the majority of the inventors fell into three basic categories: relatively ordinary workers and artisans, comprising farm labourers, bakers, carpenters, and jewellers; a more elite class of professionals, technical and white-collar inventors that included bookkeepers, engineers, and physicians; and market-oriented manufacturers and traders (merchants, salesmen,

\footnotetext{
${ }^{25}$ Joseph Ferrie generously provided access to these data. For a description of Ferrie’s project, see Joseph P. Ferrie,"Longitudinal Data for the Analysis of Mobility in the U.S., 1850-1880," available online at http://www.nappdata.org/imagpapers/ferrie.pdf.

${ }^{26}$ For patenting activities of "great inventors," see B. Zorina Khan and Kenneth L. Sokoloff, "'Schemes of Practical Utility': Entrepreneurship and Innovation among 'Great Inventors' During Early American Industrialization, 17901865," Journal of Economic History, vol. 53 (2) 1993: 289-307; and B. Zorina Khan and Kenneth L. Sokoloff, "Entrepreneurship and Technological Change in Historical Perspective: A Study of Great Inventors During Early Industrialization," Advances in the Study of Entrepreneurship, Innovation, and Economic Growth, vol. 6 (1993): 3766.

${ }^{27}$ The specification of Patent No. 37,406 stated that Oliphant's motivation owed to "the custom in the army, for the purpose of preventing accidents of this nature, to require the soldiers to march with empty guns, they not being permitted to load until they are in the immediate presence or neighborhood of the enemy, thus constantly running the risk of being suddenly surprised by an ambuscade with empty guns in their hands." (Oliphant may have belonged to the $5 \mathrm{~Pa}$. Infantry regiment in 1861.)
} 
retail and wholesale dealers.) Patentees' efforts to benefit from their investments in inventive activity through direct participation in innovation resulted in an even larger share (18.2 percent of the known occupations) for manufacturers, after the war. The increase was especially evident among inventors of war-related patents, where manufacturers increased from 10.9 to 25.7 percent. For instance, the link between patent records and manuscript censuses reveal that George B. Jewett, a clergyman in Salem, Massachusetts before the outbreak of the war, filed six patents for an improvement in artificial limbs during the war, and by 1870 was a manufacturer of his invention.

About half of all inventors filed their first patent during the Civil War. It is especially noteworthy that women increased their rate of patenting activity markedly during this period. ${ }^{28}$ Women accounted for only 72 patented inventions in the entire period before the war, but this figure jumped to 86 in the war years alone. Many of these inventions were related to the wareffort and to women's participation in nonhousehold production during this time. For instance, Mary Jane Montgomery of New York obtained an 1864 patent for a "war vessel.”29 Sarah J. A. Hussey, a Quaker from Cornwall, New York, noted in her 1865 patent specification that her invention was inspired by her "long experience as a nurse in the United States army hospitals.”30 Many of these patents were widely marketed, and a notable example was the $\$ 20,000$ which Martha J. Coston received by authority of Congress on June 5, 1862, for the rights to her chemical flares that were purchased for the use of the U.S. Navy. ${ }^{31}$ Coston founded a company and manufactured the signals at cost for the military during the course of the war.

However, the patterns of new entry differ significantly by military orientation. Approximately 40 percent (281 inventors) of general inventors were new entrants during the Civil War, whereas 58.2 percent (301) of the creators of improvements in weapons, and 74.5 percent (73) of war-related inventors were first time filers. Thus, inventors of military innovations appear to have been more responsive than the general patentee to the prospects that

${ }^{28}$ B. Zorina Khan, "Not for Ornament': Patenting Activity by Women Inventors," Journal of Interdisciplinary History, vol. 33 (2) Fall 2000: 159-195; and Zorina Khan, "Married Women's Property Laws and Female Commercial Activity: Evidence from United States Patent Records, 1790-1895," Journal of Economic History, vol. 56 (2) 1996: 356-88.

${ }^{29}$ Patent No. 41167, January 5, 1864.

${ }^{30}$ Patent No. 47831, May 23 1865, for an “improved table for hospitals.” Sarah Hussey was buried in 1898 with military honours in her hometown.

${ }^{31}$ Reports of Committees, Report No. 622 of the Committee of Patents, 48th Congress, 2nd Session of the Senate, May 17, 1880. The Bureau of Navigation of the Navy noted that "No lights or other symbols for making night signals in fleets or squadrons have been found ... in any degree comparable to those known as Coston Night Signals," p. 2, emphasis in original. 
the war offered. The age-profile of inventors at the time of first patenting indicates that they were already experienced individuals with an average age close to 40 years old. The patentees who first entered the field of invention during the war tended to be older than the average inventor, and certainly older than the general population. For instance, only 10.8 percent of the war-related inventors who first entered during the Civil War period were below the age of thirty, relative to 20.3 percent of all inventors, which may have been due to the diversion of younger men into service in the military.

Telling information on the identities of those who were making contributions to technological change during the war comes from the data on career patents (Table 3). The inventors of weaponry differed from those who created miscellaneous devices that were incidental to the war. Almost a half of the war-related inventors produced a single patent and had brief careers, and only 12.9 percent had careers of 20 years or more. By way of contrast, the 538 patentees of weapons tended to have longer careers, and they corresponding held more numerous patents, since over 22 percent filed 10 or more patents. These features are all consistent with greater specialization at invention among the inventors of weapons. Thus, the war may have led to greater technological creation (in the sense of attracting new inventors into inventive activity) among the inventors of miscellaneous war-related inventions. However, in the area of weapons, which likely required greater inventive capital or more investments for innovation, we observe higher technological diversion (in the sense of changing the orientation of existing patentees.)

Table 3 shows average patenting per inventor and patents granted over the inventor's entire lifetime across region and occupation. Career patenting was highest in the well-developed markets of the Northeast, and was otherwise quite uniformly distributed across regions. Although they lagged in terms of average patents per inventor, the frontier areas such as the West and the West North Central accounted for large surges in war-time patenting. These patterns indicate the widespread nature of the response to the anticipated growth in the market for military inventions, in terms of average patenting across location and occupation. Inventors whose birthplace was in the Middle Atlantic, and the foreign born, were especially responsive to the external shock of the conflict in terms of average patenting of military inventions. As might be expected, war veterans, who were responsible for fewer lifetime patents than the average inventor, were disproportionately likely to produce military inventions. However, among 
general inventors, the commitment to patenting fell sharply among artisans and New England residents, groups which may have suffered disproportionately from the war.

Migration - both international and internal -- has long been identified as a standard feature of the American experience, as U.S. residents remained "restless in the midst of their prosperity.”32 Geographical mobility is a key indicator of resource reallocation, and may also signal the flexibility that is necessary for entrepreneurial success. Investments in human capital are associated with higher mobility, holding other things constant, so one would expect the population of patentees to exhibit greater mobility than their less inventive counterparts. ${ }^{33}$ Inventors from other countries were disproportionately attracted by the opportunities that this country offered, and in 1860 over 20 percent of patentees were immigrants to the United States. ${ }^{34}$ England was the birthplace of fully 7.6 percent of the entire sample of inventors, and a further 5.3 percent were German-born. Native-born inventors were clustered in states where per capita patenting was especially high, and New York, Massachusetts, and Connecticut accounted for 18.7 percent, 12.3 percent and 8.6 percent respectively of total inventors in the sample. Table 4 shows that, relative to the population in general, individuals who possessed inventive capital exhibited significantly greater movement across states, regardless of how one measures geographical mobility. By 1870, 42.3 percent of the U.S. population, had moved from their birthplace to another state, but both types of inventors experienced higher mobility (53.4 percent of military and 52.8 percent of total inventors). As shown elsewhere, their destinations tended to be toward areas with greater commercial opportunities. ${ }^{35}$ Although inventors exhibited higher rates of mobility over their careers relative to the general population, the intervening war

\footnotetext{
${ }^{32}$ See Alexis de Tocqueville, Democracy in America, vol. II, Section 2, Chapter 13. Tocqueville regarded American mobility as somewhat pathological: "It is strange to see with what feverish ardor the Americans pursue their own welfare, and to watch the vague dread that constantly torments them lest they should not have chosen the shortest path which may lead to it.”

${ }^{33}$ See, for instance, Robert A. Margo, Race and Schooling in the South, 1880-1950: An Economic History. Chicago: University of Chicago Press, 1990; and Aba Schwartz, "Migration, Age and Education,” JPE vol. 84 (4) 1976: 701719. We observe the residence of patentees at each point of patenting, and a measure of migration that takes into account any recorded change in residence yields rates of inter-state migration that are exceedingly high for all inventors, military or otherwise. Table 3 defines migration more conservatively, in order to enable comparison with the general population. Lifetime migration through 1870 simply indicates any change that occurs across birthplace, location in the 1860 census, and location in the 1870 census. Since the U.S. population sample is restricted to native-born residents, the last row in the table presents the results for native-born inventors.

${ }^{34}$ The middle of the 1850s saw a rapid increase in the rate of international immigration into the United States. The 1850 census recorded that less than 10 percent of the population were immigrants, but by 186013.2 percent of the population was foreign born, and in 1870 the proportion of foreign-born residents was 14.4 percent. See Series C89119, Historical Statistics of the United States, Colonial Times to 1970, vol. 1, Wash., D.C., Government Printing Office, 1975.

${ }^{35}$ See Khan and Sokoloff, "Schemes of Practical Utility."
} 
retarded the likelihood that they would switch locations. Between 1860 and 1870 their rates of geographical mobility, and the distance between old and new locations, were approximately the same as the resident white male population. The war may have lowered expected benefits or increased the risks and costs of migration disproportionately for those with higher investments in inventive capital.

Individuals may move for personal reasons, but in many instances migration is related to job search, and both geographical and occupational mobility may be a function of similar individual characteristics such as age, inherent abilities, the accumulation of investments in human capital, and access to information over time. ${ }^{36}$ One might expect that responses to an exogenous shock such as the Civil War would vary depending on these individual characteristics. Although labour market theory does not offer a basis for predicting the direction of change, it does suggest that the share of individuals at risk for change might be negatively related to investments in human capital, because of the fall in the set of occupations that might lead to greater returns as education and skill increases. ${ }^{37}$ Table 5 presents the distribution of occupations in 1860 and 1870 for a sample drawn from the general population, as well as all inventors, and inventors of military patents. Approximately 60 percent of the U.S. population remained in the same broad job category during the intervening war, relative to 63 percent of all inventors. Persistence, or no transition across occupational classes, was the norm for the majority of inventors as well as for the population in general, but occupational persistence for war-related inventors was higher (almost 70 percent). ${ }^{38}$ As theory predicts, inventors in higher status occupations experienced greater persistence relative to the population; inventive capital

\footnotetext{
${ }^{36}$ It should be noted that this argument is based on quite broad occupational categories corresponding to general skill levels. Persistence in these categories does not rule out rapid entrepreneurial within-class changes such as a manufacturer of soap shifting to the production of lathes after he patents an improvement for the latter product. See Khan and Sokoloff, "Schemes of Practical Utility," who found that such occupational reorientation was standard among inventors of the time. There are several studies of occupational mobility during this period, including Joseph Ferrie, "Up and Out or Down and Out? The Occupational Mobility of Immigrant Non-Persisters in the Nineteenth Century U.S." Journal of Interdisciplinary History, vol 26 (Summer) 1995: 33-55.

${ }^{37}$ See Schwartz, "Migration, Age and Education."

${ }^{38}$ Among the general population, about a half of all men in market-oriented occupations (the commercial class) remained in such jobs after the war. Inventors were not only significantly more likely to remain in commercial occupations, they were also more likely to switch to such jobs after the war, arguably demonstrating greater entrepreneurial abilities by so doing. Inventors were able to move up from the unskilled worker occupations to skilled or white collar jobs to a greater extent than those without inventive capital. Workers in the general population who made the transition to another occupational class were more likely to become farmers (33.5 percent of all labourers in the general population, compared to 7 percent of war-related inventors), rather than progress to skilled or commercial pursuits. Moreover, farmers in the general population were twice more likely than inventorfarmers to fall into the labourer category. Farmers and workers who persisted in the same occupation performed worse than average in terms of both real estate and personal wealth, regardless of whether or not they possessed inventive capital.
} 
helped to avoid downward mobility, and inventors were better able to remain in skilled and white-collar occupations.

To what extent did inventors who responded to the war differ from inventors without a military orientation? Table 6 presents the results of regressions that control for a number of the possible correlates of patenting. The first two regressions show the factors that influenced variation in the number of military patents that were filed during the war, and the next two relate to the characteristics that were associated with higher numbers of military inventions over the entire period between 1855 and 1870. In general, military inventions were somewhat higher in New England and the South, but inventors who responded to the war were drawn from all regions of the country. Unlike the entire population of inventors, military patentees tended not to be geographically mobile, but those who switched occupations obtained higher numbers of patents. Perhaps surprising is the finding that technical expertise did not yield greater numbers of military inventions; instead, manufacturers and the professional class of physicians, lawyers, and other white collar workers filed the greatest number of military inventions. Other things being equal, more military patents were filed by the poorer segments of the population who owned less than \$100 in total wealth in 1860; however, this was not the case for the Civil War period. $^{39}$

The regressions attempt to directly measure unobserved heterogeneity among inventors. A significant source of heterogeneity is likely to be differences in technological or inventive capabilities across individuals. Some of these abilities may be enhanced through learning by doing, but others are more related to invariant characteristics of inventors. A possible way to model this is through fixed effects that capture the individual inventor's patent history (the stock of patents). After conditioning on inventive ability, we are better able to determine the process that gave rise to higher numbers of military patents during the war. The regression results show that individuals who responded to the war by filing patents for weaponry and war-related items tended to have had previous experience at military invention. Given that the coefficient on their total patenting in the antebellum period is negative, while the coefficient on prewar military invention is positive, this suggests that they also tended to be quite specialized in military technology.

\footnotetext{
${ }^{39}$ Regressions that control for wealth as a continuous variable (not reported here) show that its effect was minimal in explaining inventive orientation.
} 
When markets first expanded in the antebellum period, new entrants into invention tended to be rather ordinary individuals without much technical training, who responded to perceived need by filing job-related patents for improvements. Similarly, the change in market demand during the Civil War attracted a number of general inventors, and logit regressions (not reported here) of those who first patented during the war show that they tended to hold significantly lower numbers of patents over their lifetime and had shorter careers than average. It is not possible to know whether they might have started inventing even in the absence of the war, but this is unlikely to be true of weapons patentees who were active for the first time during the war. New weapons patentees tended to also be new to invention, and did not sustain their interest in patenting after the war. However, the regressions in Table 6 show that those who filed larger numbers of military patents during the war tended to have been already specialized at military invention. Thus, although the war temporarily diverted a number of individuals with relatively high endowments of human and financial capital from other activities into military production, the major response in terms of numbers of patents came from manufacturers and professionals who had already committed to this type of activity. The social returns to such reallocation are debatable, but we can be more specific about the private returns by examining whether a military orientation was associated with greater additions to personal wealth by the end of the 1860s decade.

\section{Wealth and Military Innovations}

"The race is not to the swift, nor the battle to the strong... nor yet wealth to men of understanding, nor yet favor to men of skill..." ---Ecclesiastes 9:11.

Wars can be associated with severe negative changes in circumstances for many, ranging from death to displacement. For others, however, wars presented the opportunity to benefit. Profits serve as a signal regarding the most highly-valued allocation of resources; in the absence of data on profits, changes in wealth can serve as a rough proxy for the nature of resource reallocation that the conflict rewarded. For instance, Daniel B. Wesson, the famous Springfield gun manufacturer and inventor of the Smith \& Wesson revolver, experienced an increase in wealth from $\$ 1000$ in 1860 to $\$ 350,000$ in $1870 .^{40}$ Wesson’s was undoubtedly an extreme case and the

\footnotetext{
${ }^{40}$ Wartime demand for Smith \& Wesson revolvers far exceeded the firm's ability to supply them and the firm earned over \$1million in gross income between 1862 and 1868 (See Bill S. No. 273, January 11, 1870, Senate Ex.
} 
degree to which other military patentees could emulate him depended in part on the market for new innovations.

The patent records indicate there was a rapid increase in inventive activity that was directed toward military improvements, but it is useful to know whether new technologies were actually adopted and employed in the course of the Civil War. Researchers hold conflicting views about how pervasive innovation was during this time. ${ }^{41}$ These divisions reflect those prevalent among major actors in the war itself: against the enthusiasm that many Civil War participants showed for innovations, others pointed to the need for standardization and centralization in times of large scale mobilization. ${ }^{42}$ The trials and testing of new equipment was undoubtedly costly and somewhat risky for both supplier and demander. ${ }^{43}$ It not only led to the

Doc. 23, $41^{\text {st }}$ Congress, 2d Session.) The Smith and Wesson factory in Springfield was located close to the Federal Armory. The Springfield Federal Armory was largest in the country, and produced over 800,000 rifles during the war. It grew rapidly from an establishment with 700 employees in June 1861 to 2600 employees by January 1865 (Mark Wilson, PhD diss., p. 533.)

${ }^{41}$ Engerman and Gallman, p. 247, contend that "the North fought a technologically modern war but organized around traditional assumptions and limitations." According to Thomas C. Cochran, "by modern standards, the Civil War was still unmechanized," ("Did the Civil War Retard Industrialization?” reprinted in Andreano, Economic Impact, pp. 167-179. ) A large number of monographs on individual technologies in the cavalry, infantry, Navy and even an incipient "airforce" of balloonists highlight the proliferation of innovations that were applied during the war. Charles D. Ross, Trial by Fire: science, technology, and the Civil War, Shippensburg, PA: White Mane Books, 2000, argues that a number of war commanders, such as George B. McClellan and P G T Beauregard, were ahead of their time in their support of new technologies. However, others such as Joseph G. Bilby (Civil War Firearms, Pennsylvania: Combined Books, 1996) feel that the degree of innovation was somewhat overstated, at least until the later years of the war, especially in the Confederate ranks. Guy Hartcup, The Wars of Invention: Scientific Developments, 1914-1918, London: Brassey's Defence Publishers, 1988, considered WWI to be "the first major technological war in history" (p. vii) although one doubts that he had taken much account of the experience in the American Civil War.

42 James W. Ripley, Chief of Army Ordnance wrote in June 1861 that “A great evil now specially prevalent in regard to arms for the military service is the vast variety of the new inventions, each having, of course, its advocates, insisting on the superiority of his favorite arm over all others and urging its adoption by the Government. ... This evil can only be stopped by positively refusing to answer any requisitions for or propositions to sell new and untried arms, and steadily adhering to the rule of uniformity of arms for all troops of the same kind...” cited in Bruce, p. 69. Ripley retired Sept 15, 1863. George McClellan, J.E.B. Stuart, Ambrose E. Burnside and a substantial number of military leaders were themselves successful patentees. Others such as Benjamin F. Butler, Major General of Volunteers, were enthusiastic about new technologies and quick to adopt promising innovations.

${ }^{43}$ S V Benet, Chief of Ordnance, refers (in his Letter of March 61875 to the Secretary of War) to the Statute of 185410 Stat., p. 579 appropriating $\$ 90,000$ to the purchase of breech-loading rifles. "The effect of this measure was to stimulate the ingenuity of inventors in devising and perfecting methods of operating arms at the breech; and the records of the Patent Office show, in the number of patents issued for breech-loading arms about this time, that it is here properly that the era of breechloaders in this country begins.” (p. 88) However, not much of the money was spent because the army selected carbines only for the cavalry. Ultimately, Ambrose E. Burnside's patented rifle was selected as the best because it used metallic cartridges. But the order for Burnside's rifle was subsequently cancelled. Instead the money was spent on carbines from Joslyn and on rifles by more established patentees Colt, Maynard, and Sharp (Fuller and Steuart, p. 89). As for the suppliers, there was substantial leeway in fulfilling their obligations, since "Most of the contracts with State or private armories specified an arm "of the value and description of the Enfield or Mississippi rifle" and this obviously left a great many of the details to suit the maker" (p. 156.) 
possibility of hold-ups by either party; it further created the potential for corruption in the requisitions process. ${ }^{44}$ Innovations in manufacturing inputs or final products might reduce the future cost of production and increase military productivity, but some officials were more concerned that they might divert funds away from current production. ${ }^{45}$

Equally scattered evidence suggests that patentees were not labouring entirely in vain, even in the South. The Confederate Congress offered subsidies of as high as 50 percent to firms that established manufactories, which may have reduced the incentive to invest in other forms of appropriation. $^{46}$ Although armories in the South employed over 5000 people, especially in Richmond and Fayetteville, the majority of Confederate firearms were purchased elsewhere. ${ }^{47}$ Still, at least some of the new patented inventions filed in the Confederacy were produced. ${ }^{48}$ In the North, a number of the most successful patentees were career officers such as Thomas J. Rodman, Robert P. Parrott, John A. Dahlgren (inventors of guns, projectiles and ordnance), and Henry H. Sibley (the patentee of Sibley's conical tent, which was one of the most widely used tents in the army at the time.) Others were experienced patentee/manufacturers such as Edward Maynard, Samuel Colt, Christopher Spencer, Oliver Winchester, Christian Sharp, Eli Remington

\footnotetext{
${ }^{44}$ This would be the charitable rationale for the actions of Senator Jefferson Davis of Mississippi, who inserted a clause into the appropriations bill for the year ending June 1861: "No arms nor military supplies whatever, which are of a patented invention, shall be purchased, nor the right of using or applying any patented invention, unless the same shall be authorized by law and the appropriation therefore explicitly set forth that it is for such patented invention" (Fuller and Steuart, p. 92). The uncharitable would point to the fact that Davis decamped for the Confederacy shortly afterwards as consistent with the notion that it was an attempt at technological destabilization. The Annual Report of the Secretary of War for 1860 requested an appropriation of " $\$ 50,000$ for experiments for the improvement of arms and military supplies," and protested the law regarding the purchase of patented weapons. S V Benet, Chief of Ordnance, Letter of March 61875 to the Secretary of War. The Jefferson Davis statute was quickly repealed.

${ }^{45}$ This view is expressed in a letter from H K Craig, Chief of Ordnance, to Joseph Holt, interim Secretary of War, Washington, Jan. 8, 1861: "The number of arms manufactured at the national armories during the last year was not as great at the available funds would have justified. This diminution is in a measure attributable to the diversion of armory operations from the manufacture of arms of the established model to the alteration of arms according to plans of patentees and to getting up models of arms for inventors.” (Fuller and Steuart, p. 8.)

46 "One of the first steps taken by the Confederate Government to obtain arms was to encourage home industries by subsidies. On January 13, 1862, Congress passed an Act providing for an advance of 50 percent of the capital of any firearms manufacturing company.” (Fuller and Steuart, p. 250)

47 The Confederate government sent agents to Europe and even to Cuba and Mexico. They also smuggled arms from the North. Josiah Gorgas, the Confederate Chief of Ordnance, reported in 1864 that "we have hitherto had no difficulty in importing arms through the blockaded seaports," and the greatest barrier they faced was lack of funds. (Fuller and Steuart, p. 108)

${ }^{48}$ See Fuller and Steuart, Firearms of the Confederacy: Dr. Jean Alexander LeMat of Louisiana received an order for 5000 of his patented revolvers which were manufactured in France. Nathan T. Read manufactured his patented firearm at Keen, Walker \& Co's establishment in his hometown of Danville, Virginia (p. 157). Thomas Cofer's Confederate patent of August 12, 1861 was granted for a revolver that was manufactured in Portsmouth, Virginia. (p. 263). Patent No. 32316 for a magazine rifle, which the USPTO granted in May 141861 despite the outbreak of hostilties, was issued to the Virginian Lorenzo Sibert, and was produced in the Confederacy.
} 
and Simeon North. But the outside contracting method meant that even small-scale producers were able to benefit from the military market. ${ }^{49}$ For instance, George W. Morse obtained orders for his patented breech-loading arms, which he manufactured during the war. ${ }^{50}$ Moreover, military commanders had significant discretion in placing orders on their own accord for equipment that incorporated promising innovations, bypassing the formal requisitions process, and many chose to do so. ${ }^{51}$ Further evidence that a remarkably diverse array of patented items were in widespread use during the war can be gleaned from archaeological findings at prominent battlefields. ${ }^{52}$

Figure 4 provides more systematic information that bears on the extent of innovation or applied invention during the war. It shows the percentage of patents that were assigned (sold) at the time that the patent was granted, calculated from the records for all patents filed in the United States. The general trend between 1850 to 1880 is positive, with the proportion of patent assignments growing from 5.3 percent in 1850 to 22.6 percent in 1880. The Civil War boosted the sale of patent rights from 10.4 percent in 1860 to over 14 percent during the entire period of the conflict. The rate then fell from 14.2 percent in 1865 to 11.7 percent in 1866 . What sorts of improvements were being sold at the time of patenting? Between 1861 and 1865, fully 48.1 percent of patents that the sample of inventors assigned were for military inventions. ${ }^{53}$ Thus, not only was the market for inventions flourishing in the middle of a devastating conflict, it seemed to effectively allocate inventive resources toward the war effort. Patented inventions may have

\footnotetext{
49 According to Stanley Engerman and Matthew Gallman, "the wartime procurement system left the Northern economy largely in the hands of small entrepreneurs who responded to market incentives rather than to government incentives” p. 243, “The Civil War economy: a modern view," in Stig Förster and Jörg Nagler (eds), On the road to total war : the American Civil War and the German Wars of Unification, 1861-1871, Washington, D.C.: German Historical Institute ; Cambridge [England] ; New York : Cambridge University Press, 1997. Procurement of military equipment and provisions involved a mixed supply system with centralized government production, but with a substantive amount of outsourcing to private firms. The most comprehensive account of military procurement and expenditures is Mark R. Wilson, The Business of Civil War: Military Enterprise, the State and Political Economy in the United States, 1850-1880, Ph.d. Dissertation, University of Chicago, Illinois, 2002. For a discussion of the Northern Navy's relationship with private firms see William H. Roberts, Civil War Ironclads: the U.S. Navy and Industrial Mobilization, Baltimore: Johns Hopkins Press, 2002.

${ }^{50}$ See Fuller and Steuart, p. 91. Since many of these orders were for alterations of existing weapons, patent innovations were not necessarily reflected in tallies of new production.

${ }^{51}$ Robert V. Bruce identifies Frémont, McClellan and Benjamin F. Butler as particularly active in this regard (p. 72).

${ }^{52}$ See, for instance, www.civilwarartillery.com.

${ }^{53}$ However, peripheral war-related items were riskier, and only 5.9 percent of the patents in the sample were assigned. Farmers were the only group that had a significantly lower than average propensity to assign, and across income class inventors without any wealth were slightly more likely to be assignees. My data on assignments are quite incomplete and unrepresentative because the sample includes only one patent per inventor at the time he or she was selected. It should also be noted that patents could be sold anytime during their term and after 1861 the life of a patent was 17 years from date of issue.
} 
been sold and presumably used, and a number of patentees like Wesson may have amassed riches. Still, a key question remains whether contributions to the war effort made a significant difference in the returns to the average inventor.

If technological improvements served to increase military productivity, it might be expected that this would be reflected in greater returns and financial mobility for military inventors, holding other things constant. ${ }^{54}$ Both the 1860 and 1870 censuses include entries on real estate and personal wealth, which allows us to examine this hypothesis in terms of wealthholding directly before and after the war. ${ }^{55}$ Lee Soltow found it to be "rather shocking" that 57 percent of white men in 1860 possessed no real estate wealth, and 43 percent owned no personal estate, a pattern that was maintained in $1870 .{ }^{56}$ The implications from Table 7 regarding the distribution of inventors' wealth by asset level are somewhat more optimistic. They indicate that, like the rest of the white male population, on the eve of the outbreak of war, over a half of all inventors held no real estate, and over a third recorded no personal wealth. Poor inventors were somewhat more likely to assign their inventions so it is not surprising that, unlike the general population, many of these inventors succeeded in acquiring assets within the decade. Inventors without property were more likely to file patents for military technology, perhaps because a military orientation was associated with significantly higher wealth on average. However, the evidence on the returns to switching to military inventions is less clear cut. Table 7 indicates that the average real estate wealth for inventors with first-time military patents fell by $\$ 287$ between 1860 and 1870, and the change in their personal wealth was below the average for all inventors. Thus, given that an individual had made investments in invention, the focus on warrelated inventions did not typically lead to higher returns relative to other types of inventions.

Table 8 includes regressions of the factors that were associated with differences in personal wealth in 1870, after controlling for wealth in 1860. Among the white male population (the first regression) manufacturers and artisans experienced a fall in prosperity over this period relative to all other classes. As might be expected, the accumulation of wealth was positively

\footnotetext{
${ }^{54}$ Richard H. Steckel and Carolyn M. Moehling,"Rising Inequality: Trends in the Distribution of Wealth in Industrializing New England," Journal of Economic History 61 (1) 2001: 160-183, attribute increases in wealth inequality during the nineteenth century to "luck, rents, and entrepreneurship."

${ }^{55}$ The censuses included information on real estate wealth, exclusive of "liens or encumbrances," and personal estate comprising all personal property "consist of what it may." These entries are not entirely accurate, because of missing values, left-censoring of observations around values of \$100, and "clumping" around popular figures such as round hundreds.

${ }^{56}$ See Lee Soltow, Men and Wealth in the United States, 1850-1870, New Haven: Yale University Press, 1975, p. 60. "Patterns [between 1860 and 1870]... were remarkably stable. The most striking finding was that this country harbored vast proportions of populations with no wealth” (p. 61).
} 
related to age, and to prior stocks of assets. The regressions for the inventors show that their wealth varied little in terms of the geographical location of their patenting - possibly because they tended to move towards areas with better prospects, although the war reduced the tendency to migrate. Occupation played a significant role in explaining additions to wealth over this period, and job persistence was associated with higher returns. Unlike the rest of the white male population, inventors with a commercial orientation (traders and manufacturers) and those in more developed urban markets benefited the most over the decade. This is consistent with previous research on "great inventors" that found greater income was derived from innovation than from inventive activity per se. Thus, additions to personal wealth over the decade were associated with entrepreneurial responses to changes in the market.

The wealth regressions include fixed effects for technological capability, as discussed before. Some of these abilities may be enhanced through learning by doing, but others are more related to invariant characteristics of inventors. The stock of all patents accumulated prior to the war controls for inherent ability, whereas the stock of all patents filed during the war proxies for learning by doing. There is no evidence of returns to learning by doing, but more committed inventors (those who filed greater numbers of patents) were rewarded with higher returns. After controlling for heterogeneity across inventors, the regression considers the experience of those who responded to the war. New entrants to invention during the war, irrespective of their military orientation, did not benefit a great deal from their efforts. The regressions include variables to represent inventors who had filed a nonmilitary patent before the war and switched to military inventions during the war, and those who had had prior experience at invention but did not switch to military invention. Although both classes of inventors had lower returns, the coefficient on nonmilitary inventors with prior experience is not significant. However, the experienced patentees who switched into military invention during the war were disappointed in their expectations, since they obtained significantly lower returns. Although one might expect that this finding is driven by those in white-collar occupations who might have been less adept at innovation, the results hold more for manufacturers. Why this might have been the case is a question for further research, but part of the answer may be due to the decentralized nature of procurement that precluded the benefits of economies of scale. Another part of the answer is undoubtedly related to the experience of modern providers of military supplies and equipment, who have similarly found that the risks far outweighed the return, leading to substantial financial and real losses rather than excess returns. 


\section{CONCLUSION}

Sheridan, evidently an optimist regarding the role of weapons technology, thought that "the improvement in the material of war was so great that nations could not make war, such would be the destruction of human life."57 The Civil War was indeed a landmark event in military technology, as large numbers of individuals reoriented their attention to the expanding market for improved methods of destruction and to satisfy the needs of the military. The patent records show that this response was uniform across all regions except the South. New entrants into nonmilitary invention during the war tended to be impoverished inventors, who were less likely to have the resources or the reputation to commercialize their inventions. Such inventors benefited from markets in invention, which allowed them to assign or sell their rights to investors, and their material circumstances after the war improved to the extent that they caught up with their peers.

Sombart contended that the net outcome of wars on the economy and technology was positive. However, the tentative conclusion of this study is that such assertions are suspect and the evidence instead seems to suggest that the war may have resulted in a misallocation of technological resources. The war reduced the tendency to migrate that was a feature of entrepreneurship and innovation in the antebellum and postbellum periods. Technological innovation prior to the war yielded higher average returns to inventors, but during the war was not associated with significant advances in financial prosperity, possibly because the large increase in military innovations drove down the marginal return. Patentees who shifted into the market for military technology while the conflict was ongoing provide the best example of reasons to believe that the war was associated with some degree of resource misallocation. These individuals tended to be professionals, a class with arguably higher opportunity cost. Moreover, their attention to military inventions was not sustained in the postwar period and for good reason since, unlike other inventors, they experienced a fall in personal wealth.

Fortunately, Nef was equally incorrect in his view that wars destroyed the capacity for future technological progress. For, perhaps the most telling indicator of the way that wars affect the potential for sustained improvements in material well-being comes not from the Civil War era itself, but from the resilient and dramatic surge in inventive activity at its close. It was the

57 See Robert V. Bruce, Lincoln and the Tools of War, p. 298-99. 
outbreak of peace, not war, that propelled the United States toward the higher trajectory of productivity and achievement that would establish it as the foremost industrial nation of the twentieth century. 


\section{BIBLIOGRAPHY}

Andreano, Ralph (ed), The Economic Impact of the American Civil War, Cambridge, MA: Schenkman Pub. Co., 1962.

Angevine, Robert G., The railroad and the state: war, politics, and technology in nineteenth-century America, Stanford: Stanford University Press, 2004.

Beller, Susan Provost, Medical practices in the civil war. Cincinnati, Ohio. Betterway Books, 1992.

Bilby, Joseph G., Civil War Firearms, Their Historical Background, Tactical Use and Modern Collecting and Shooting, Conshohocken, PA: Combined Books, 1985.

Browning Jr, Robert M., Success is All That Was Expected: The South Atlantic Blockading Squadron during the Civil War,Wash., DC: Brassey’s, Inc, 2002.

Bruce, Robert V., Lincoln and the Tools of War, Indianapolis: Bobbs Merrill Co., 1956.

Costa, Dora and Matthew Kahn, "Cowards and Heroes: Group Loyalty in the American Civil War," Quarterly Journal of Economics 118 (2) 2003: 519-548.

Engerman, Stanley L. and J. Matthew Gallman, “The Civil War economy: a modern view,” in Stig Förster and Jörg Nagler (eds), On the road to total war : the American Civil War and the German Wars of Unification, 1861-1871, Washington, D.C. : German Historical Institute ; Cambridge [England] ; New York : Cambridge University Press, 1997.

Evans, Charles M., The War of the Aeronauts: A History of Ballooning During the Civil War, Mechanisburg, PA: Stackpole Books, 2002.

Ferrie, Joseph P., Yankeys Now: Immigrants in the Antebellum U.S., 1840-1860, New York and Oxford: Oxford University Press and NBER, 1999.

Ferrie, Joseph, "Up and Out or Down and Out? The Occupational Mobility of Immigrant Non-Persisters in the Nineteenth Century U.S." Journal of Interdisciplinary History, vol. 26 (Summer) 1995: 33-55.

Fuller, Claud E. and Richard D. Steuart, Firearms of the Confederacy, Huntington, WVA: Standard Publications, 1944.

Gilchrist, David T. and W. David Lewis (eds), Economic Change in the Civil War era, Greenville, De: Eleutherian Mills-Hagley Foundation, 1965.

Goldin, Claudia D. and Frank D. Lewis, "The Economic Cost of the American Civil War: Estimates and Implications,” Journal of Economic History, Vol. 35, No. 2. (Jun., 1975), pp. 299-326.

Griliches, Zvi, "Patent Statistics as Economic Indicators: A Survey." Journal of Economic Literature, Vol. XXVIII (December 1990): 1661-1707.

Hagerman, Edward, The American Civil War and the Origins of Modern Warfare, Indianapolis: Indiana University Press, 1988.

Hazlett, James C., Edwin Olmstead, M. Hume Parks, Field Artillery Weapons of the Civil War, Newark: University of Delaware Press, 1983. 
Johnson, Russell L., Warriors into workers: the Civil War and the formation of urban-industrial society in a northern city, New York: Fordham University Press, 2003.

Khan, B. Zorina, The Democratization of Invention: Patents and Copyrights in American Economic Development. NBER and Cambridge University Press (2005).

Khan, B. Zorina, "'Not for Ornament': Patenting Activity by Women Inventors," Journal of Interdisciplinary History, vol. 33 (2) Fall 2000: 159-195.

Khan, B. Zorina and Kenneth L. Sokoloff, "'Schemes of Practical Utility': Entrepreneurship and Innovation among 'Great Inventors' During Early American Industrialization, 1790-1865," Journal of Economic History, vol. 53 (2) 1993: 289-307.

Khan, B. Zorina and Kenneth L. Sokoloff, "Institutions and Technological Innovation During Early Economic Growth: Evidence from the Great Inventors of the United States, 1790-1930,” in Institutions and Economic Growth, (eds) Theo Eicher and Cecilia Garcia-Penalosa, MIT Press (2006):123-158.

Koistinen, Paul A. C., Beating Plowshares into Swords: the Political Economy of American Warfare, 1606-1865, Lawrence, KS: University of Kansas Press, 1996.

McBride,William, Technological Change and the United States Navy, 1865-1945, Baltimore: John Hopkins University Press, 2000.

McPherson, James M., Ordeal by fire: the Civil War and Reconstruction, Boston: McGraw-Hill, 2001.

Mindell, David A., War, Technology and Experience Aboard the USS Monitor, Baltimore: John Hopkins University Press, 2000.

Neely Jr, Mark E., “Was the Civil War a Total War?” in Stig Förster and Jörg Nagler (eds), On the road to total war : the American Civil War and the German Wars of Unification, 1861-1871, Cambridge [England]; New York : Cambridge University Press, 1997.

Ott, Katherine, David Serlin, and Stephen Mihm (eds), Artificial Parts, Practical Lives: Modern Histories of Prosthetics, New York: NYU Press, 2002.

Richardson, Heather C., The Greatest Nation of the Earth: Republican Economic Policies during the Civil War , Cambridge, MA: Harvard University Press, 1997.

Roberts, William H., Civil War Ironclads: The U.S. Navy and Industrial Mobilization, Baltimore: Johns Hopkins Press, 2002

Ross, Charles D., Trial by Fire: Science, Technology and the Civil War, Shippensburg, PA: White Mane Books, 2000.

Smith, Merritt Roe, Harpers Ferry Armory and the New Technology, Ithaca: Cornell University Press, 1977.

Sokoloff, Kenneth L. and B. Zorina Khan, "The Democratization of Invention during Early Industrialization: Evidence from the United States," Journal of Economic History, vol. 50 (2) 1990: 36378. 
Squires, J. Duane, “Aeronautics in the Civil War,” American Historical Review, Vol. 42, No. 4. (Jul., 1937), pp. 652-669.

Steckel, Richard H. and Carolyn M. Moehling. 2001. "Rising Inequality: Trends in the Distribution of Wealth in Industrializing New England." The Journal of Economic History 61 (1): 160-183.

Surdam, David G., Northern Naval Superiority and the Economics of the American Civil War, Columbia: University of South Carolina Press, 2001

Thomas, Dean S., Cannons: An Introduction to Civil War Artillery, Arendtsville, PA: Thomas Publications.

Wilson, Mark R., The Business of Civil War: Military Enterprise, the State and Political Economy in the United States, 1850-1880, Ph.d. Dissertation, University of Chicago, Illinois, 2002.

Wilson, Mark R., The Business of Civil War: Military Mobilization and the State, 1861-1865, Baltimore: Johns Hopkins University Press, 2006 
Figure 1

Patents for Weapons and Total Patents Granted, 1840-1925

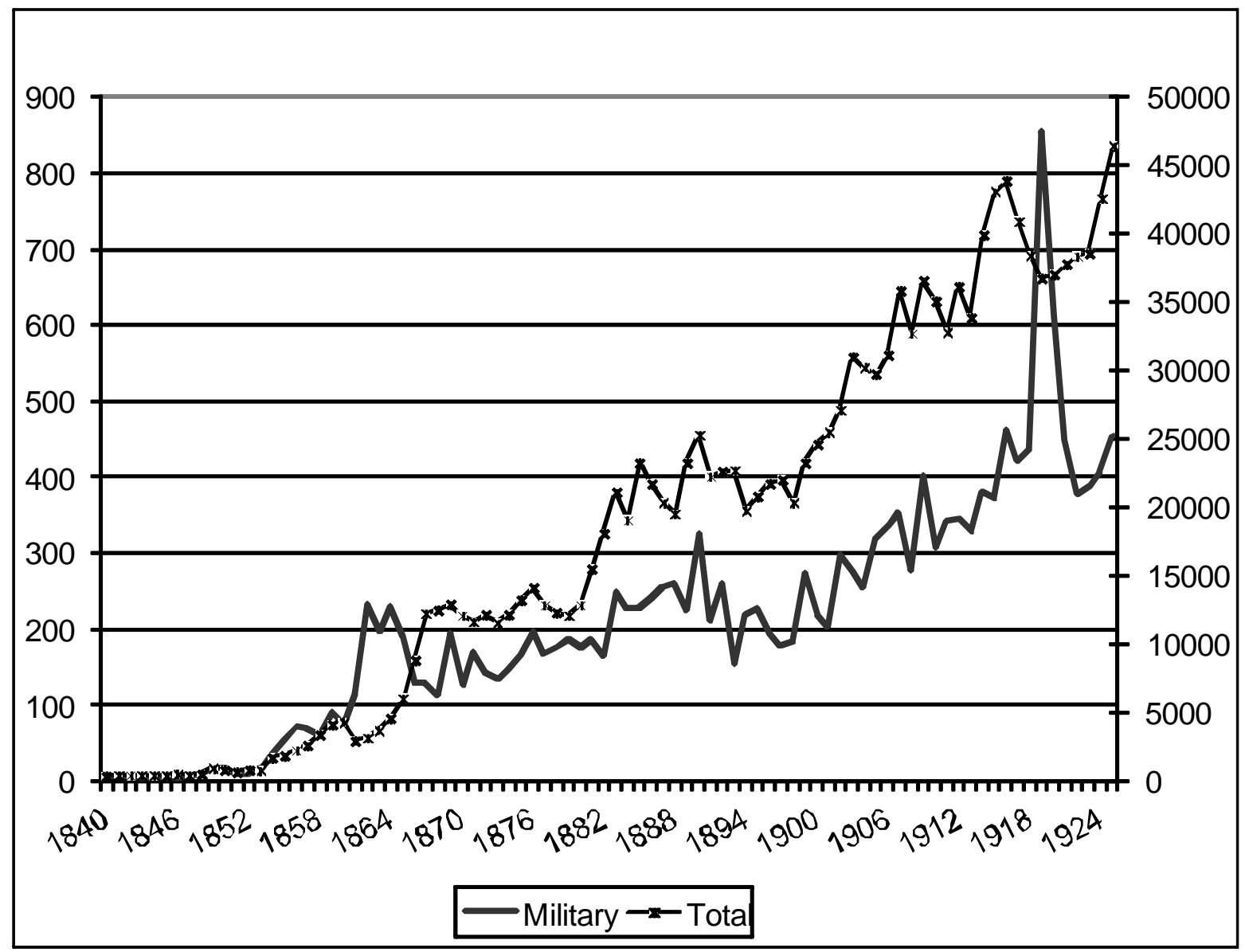

Source: U.S. Patent Office Annual Reports. Weaponry is defined as inventions within patent classes 42 (firearms); 86, 102 and 149 (ammunition and explosives); 89 (ordnance); and 124 (mechanical guns). 
Figure 2

Weaponry as a Percent of U.S. Total Patents, 1840-2000

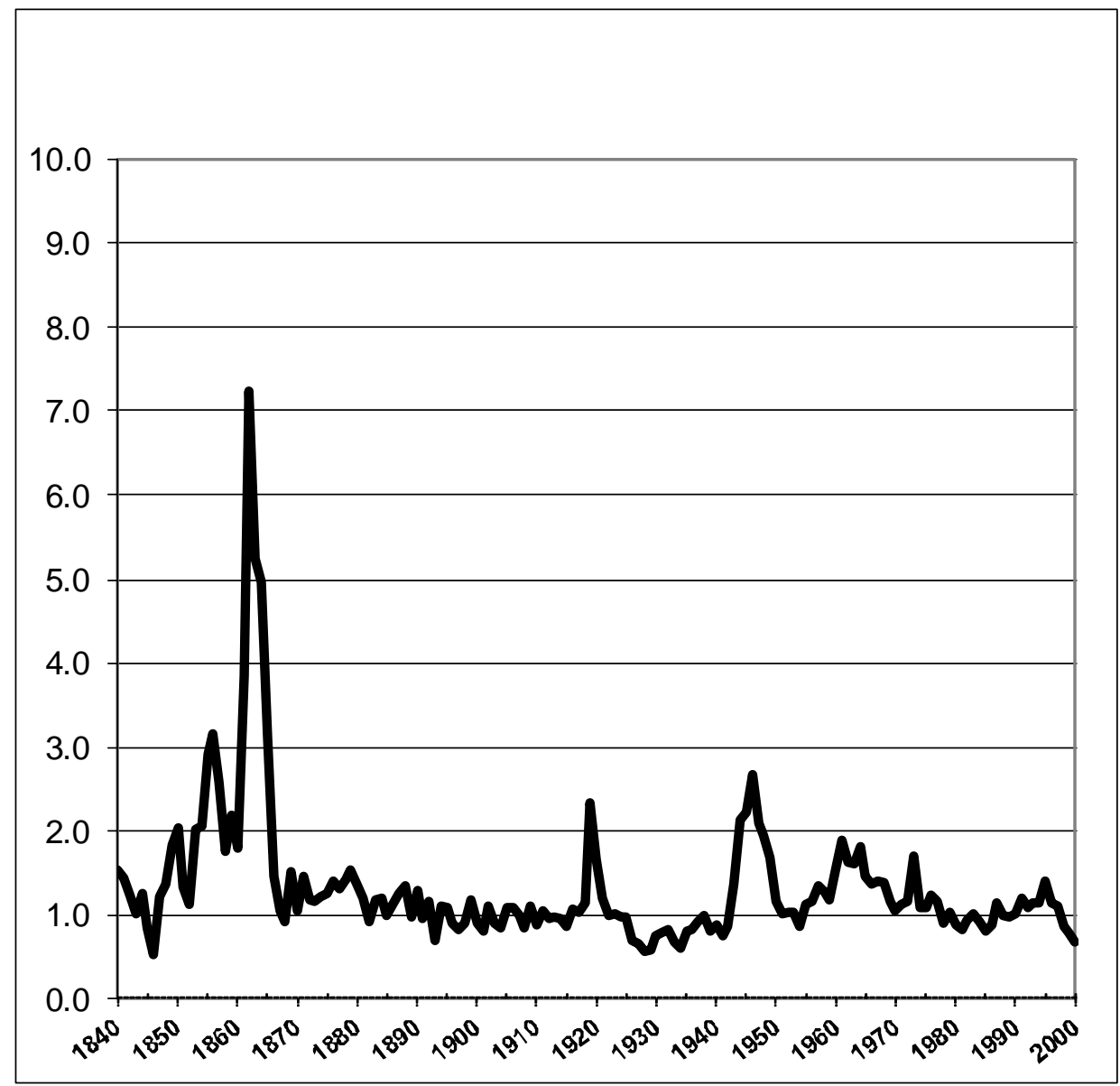

Source: U.S. Patent Office Annual Reports. Weaponry is defined as inventions within patent classes 42 (firearms); 86, 102 and 149 (ammunition and explosives); 89 (ordnance); and 124 (mechanical guns). 
Figure 3

Prosthetic Patents per Capita, 1840-1960

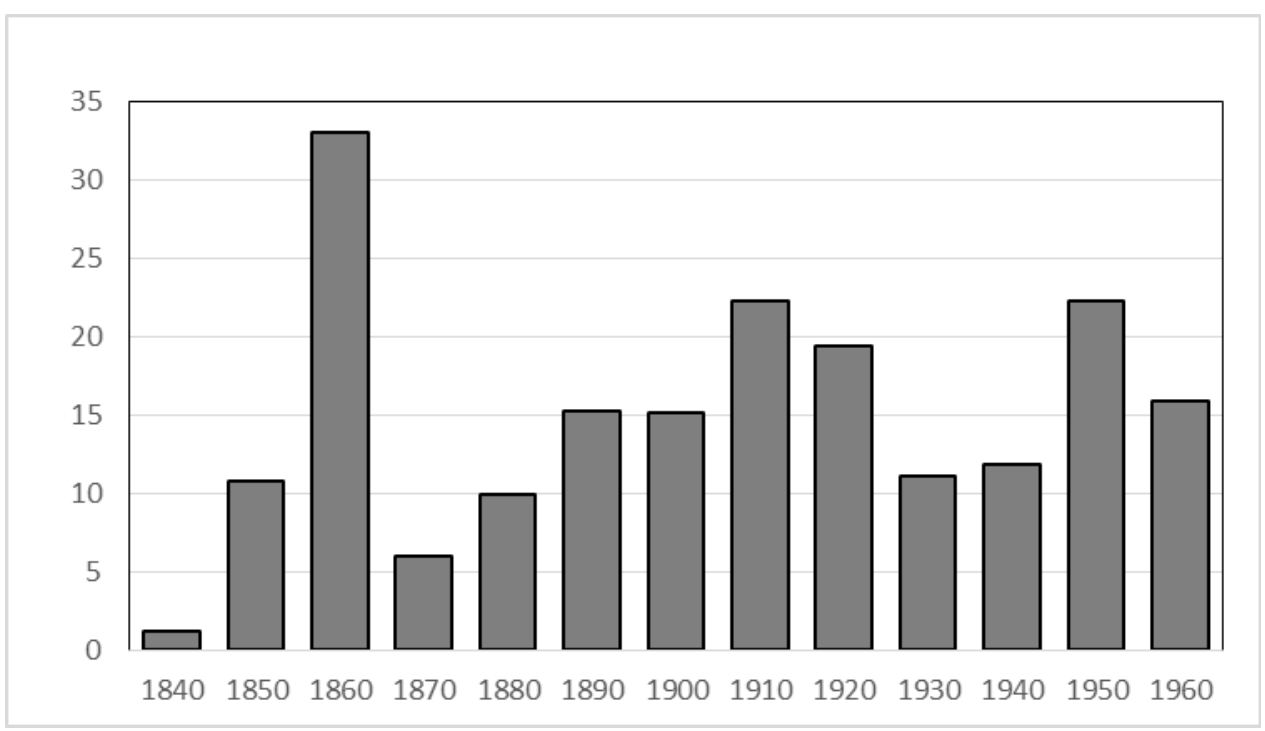

Source: U.S. Census, and Patent Office Annual Reports.

\section{【BWT2T2'B \\ Patent Artificial Legs !}

OFFCE of THE J:Wrir PATpse LFa Co.,

THESE limbs are manufactured by the Pa-

tented, under a special contract with the Government, and supplled to the soldlers free of chargo.

The Patenteo claims for them a superiority over all other patouta, for tbeir.STipexotu, DeraniLity, Liantnegs, Pehpact Fixibi, sinilicity of ConstruoT10N, and case with whlch those parts liable in all artilcial limbs to becone worv or disarranged can be replaced and aljusted, without the trouble, oxpense, and very greast inconvenlence of sending tho limb back to the tasnufactory for repair.

8oldiersand Salors whe have lost their limbs in the servico aro entitled to ono without cliarge, and all inforination regarding the modo of proceeding will bo chcerfully given by applying at tho offlce, or by lettor directed to

ABO. B. FOSTRR,

sep 28 Imulin"

33 Tremont at, Boston.

Hartford Daily Courant, p. 3 September 30, 1865 
Figure 4

THE MARKET FOR INVENTIONS DURING THE CIVIL WAR

Percentage of Patents Assigned at Issue, 1850-1880

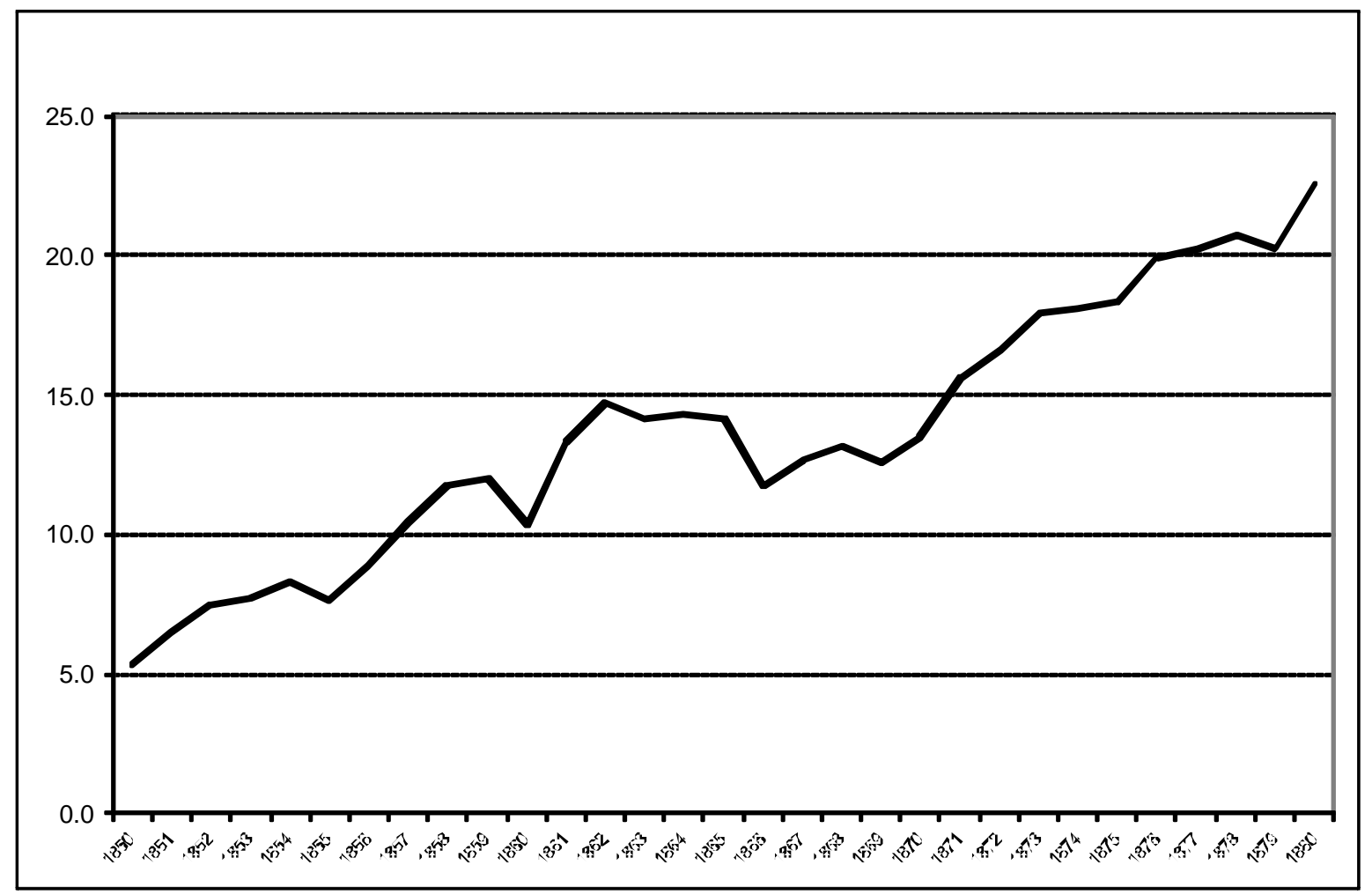

Source: U.S. Patent Office Annual Reports. These data do not account for patents that were licensed, nor do they include patents that were assigned after the date of granting. 
TABLE 1

PATENTING AND POPULATION, 1830-1900

Pre-1861 Eve of War Civil War Postwar 1870

1880s

1890s

New England

Patents per capita $\quad 102.1 \quad 260.1 \quad 308.1$

(484.4)

$\begin{array}{llll}\text { Total patents (\%) } & 28.0 & 23.8 & 22.8\end{array}$

22.8
9.5

746.3

725.3

820.2

698.4

Total pop. (\%) $\quad 10.0$

22.5

19.8

17.8

15.8

$8.8 \quad 8.2$

7.9

Middle Atlantic

Patents per capit

$\begin{array}{lll}70.4 & 212.4 & 236.5\end{array}$

(346.7)

Total patents (\%)

$45.9 \quad 41.1$

42.3

Total pop. (\%)

23.7

23.4

506.5

561.3

626.4

547.0

37.4

38.9

35.7

33.3

22.3

21.6

21.3

\section{East North Central}

Patents per capit

Total patents (\%)

$19.9 \quad 114.6$

124.0

(212.7)

Total pop

12.0

17.9

21.2

22.9

340.3

317.0

417.3

409.4

24.5

22.5

24.7

25.8

22.8

22.5

22.1

West North Central

Patents per capita

$6.1 \quad 72.7$

53.6

171.9

204.0

277.9

269.2

Total patents (\%)

$1.2 \quad 2.4$

(102.6)

Total pop. (\%)

6.9

3.0

4.4

6.2

8.4

9.5

8.3

9.8

11.4

12.3

$\underline{\text { West }}$

$\begin{array}{llcl}\text { Patents per capita } & 5.0 & 83.3 & \begin{array}{l}90.9 \\ (175.8)\end{array} \\ \text { Total patents (\%) } & 0.3 & 1.0 & 1.9 \\ \text { Total pop. (\%) } & 2.0 & & 2.2\end{array}$

$\underline{\text { South }}$

Patents per capita

$\begin{array}{lll}3.0 & 46.5 & 18.5\end{array}$

(41.9)

$\begin{array}{lllll}\text { Total patents } & (\%) & 12.7 & 12.2 & 4.4\end{array}$

$\begin{array}{llll}\text { Total pop. } & \text { (\%) } & 35.4 & 33.7\end{array}$

193.6

367.7

464.2

504.6

1.8

3.0

2.6

4.1

5.6

3.3

3.9

UNITED STATES

$36.4 \quad 130.6$

$129.5(202.4) \quad 316.2$

322.1

91.5

107.0

107.6

$6.2 \quad 9.5$

9.3

10.0

33.6

32.9

32.5

\section{UNITED STATES}

Notes and Sources: The data around the Civil War period were derived from a random sample of 1074 patents filed on the eve of the war (1855, 1857, 1859 and 1860); 2070 patents filed each year between 1861 and 1865 (inclusive); and 1990 patents filed in the immediate postwar period (1866 and 1867). Data for total patents during the other years were computed from the Annual Report of the Commissioner of Patents for 1891. Population data are from the Census of the United States, computed at the decadal midpoint by exponential interpolation. Patents per capita are per million residents, and the entries are inflated to the decadal total; hence, the italicized per capita figures for the Civil War period refer to the total if the war pattern had lasted for the entire decade, whereas the figures in parentheses show the actual per capita figures for the decade of the 1860s. 
Table 2

CHARACTERISTICS OF INVENTORS IN THE SAMPLE

AGE AT TIME OF FIRST INVENTION (Column Percent)

General Inventions Weaponry War-related Inventions All Inventors

OCCUPATIONS IN 1860 AND 1870 (Column Percent)

\begin{tabular}{|c|c|c|c|c|c|c|c|c|}
\hline & Gener & Inventions & Weap & hry & War-1 & ated Inventions & All In & entors \\
\hline & 1860 & 1870 & 1860 & 1870 & 1860 & 1870 & 1860 & 1870 \\
\hline Artisans & 20.3 & 16.3 & 17.7 & 12.8 & 17.8 & 16.8 & 19.1 & 15.0 \\
\hline Blacksmiths & 2.8 & 2.4 & 1.9 & 1.1 & 1.0 & 0.0 & 2.3 & 1.7 \\
\hline Engineers & 2.4 & 1.5 & 3.9 & 3.9 & 0.0 & 1.0 & 2.8 & 2.4 \\
\hline Inventors & 1.0 & 5.4 & 1.7 & 4.3 & 1.0 & 0.0 & 1.3 & 4.6 \\
\hline Machinists & 9.4 & 9.2 & 10.8 & 6.5 & 7.9 & 3.0 & 9.9 & 7.7 \\
\hline Farmers & 11.9 & 12.6 & 5.8 & 4.8 & 6.9 & 4.0 & 9.1 & 8.9 \\
\hline Medical & 2.8 & 1.5 & 5.2 & 3.5 & 12.9 & 6.9 & 4.5 & 2.7 \\
\hline Merchants & 2.6 & 1.7 & 3.9 & 3.4 & 4.0 & 3.0 & 3.2 & 2.4 \\
\hline Manufacturers & 8.5 & 15.8 & 9.9 & 11.9 & 10.9 & 25.7 & 9.2 & 15.0 \\
\hline Military & 0.1 & 0.1 & 5.2 & 4.8 & 1.0 & 2.0 & 2.2 & 2.1 \\
\hline Professionals & 5.6 & 5.7 & 5.9 & 5.2 & 7.0 & 7.0 & 5.8 & 5.6 \\
\hline Laborers & 10.1 & 9.6 & 6.5 & 3.9 & 5.0 & 2.0 & 8.3 & 6.8 \\
\hline Traders & 5.1 & 6.5 & 4.8 & 3.2 & 6.9 & 6.0 & 5.2 & 5.2 \\
\hline None & 5.7 & 2.8 & 2.2 & 2.0 & 0.0 & 1.0 & 3.9 & 2.4 \\
\hline Unknown & 11.7 & 9.0 & 14.7 & 28.6 & 17.8 & 22.8 & 13.3 & 17.7 \\
\hline \# INVENTORS & 720 & 720 & 538 & 538 & 101 & 101 & 1359 & 1359 \\
\hline
\end{tabular}

INVENTORS BY TOTAL NUMBER OF PATENTS FILED OVER LIFETIME

(Column Percent)

General Inventions Weaponry War-related Inventions All Inventors

$\begin{array}{lllll}\text { One patent } & 31.3 & 28.6 & 46.5 & 31.4 \\ \text { 2-4 patents } & 32.0 & 27.9 & 29.7 & 30.2 \\ \text { 5-9 patents } & 21.8 & 21.4 & 11.9 & 20.9 \\ \text { 10-19 patents } & 9.5 & 12.8 & 9.9 & 10.8 \\ \text { 20 patents and above } & 5.4 & 9.3 & 2.0 & 6.7 \\ & & & & 6.3 \\ \text { AVERAGE PATENTS } & 6.0 & 7.2 & 3.9 & 1359 \\ \text { \# INVENTORS } & 720 & 538 & 101 & \end{array}$


INVENTORS BY LENGTH OF PATENTING CAREER

(Column Percent)

$\begin{array}{lllll}\text { One year } & 32.9 & 31.1 & 49.5 & 33.4 \\ \text { 2-4 years } & 11.4 & 7.3 & 3.0 & 9.1 \\ \text { 5-9 years } & 10.4 & 13.2 & 18.8 & 12.2 \\ \text { 10-19 years } & 22.9 & 20.5 & 15.8 & 21.4 \\ \text { 20 years and above } & 22.4 & 27.9 & 12.9 & 23.9 \\ \text { AVERAGE CAREER } & 11.3 & 12.8 & 7.6 & 11.6\end{array}$

Notes: The data comprise a stratified random sample of 1359 inventors who filed at least one patent between 1855 and 1870, and who could be traced in the 1860 and/or the 1870 manuscript censuses. The strata include 720 patentees of general inventions; and military inventors, who include 538 patentees of weaponry and 101 patentees of war-related inventions. 255 of the patentees were located from patents filed in the period from 1855 to the Civil War; 673 from the Civil War period; and 431 from the post bellum period through 1870. I traced all patents for each individual in the entire sample over their lifetime. The inventors in the sample filed a lifetime sum of 1842 military patents and 8542 total patents. 'General inventions' refer to patents that are unrelated to war or the military. 'Weaponry' includes patents for firearms, cannon, ordnance, and explosives. 'War-related inventions' comprise miscellaneous patents other than weapons that mentioned war and the military in the specifications or were incidental to the war (such as uniforms, knapsacks, tents, canteens, shields for warships, artificial limbs, and military signals). The length of the inventor's patenting career was measured by the difference between the first and last patent filed plus one year.

Of the inventors in the sample, 1177 were traced in the 1860 census, 1120 in the 1870 census, and 974 in both censuses. In the first instance, I matched the name of the patentee and the residence of the patentee, as given in the patent records, with the entry in at least one of the censuses. Matches across the decade were made on the basis of name, birth date, birth place, and (only if the patentee had a family) the identities of family members. The likelihood of a match increased with proximity of the year of patenting to the year of the census. Information retrieved from the censuses include birth year and birth place, occupation, residence, migration, real estate wealth, and personal wealth. The sample includes 147 inventors who were identified as veterans of the Civil War, 745 who did not appear in war records, and 467 whose status as veterans could not be determined. 
Table 3

LIFETIME PATENTS AND AVERAGE NUMBER OF PATENTS PER INVENTOR, BY TYPE OF INVENTION, REGION AND OCCUPATION

\begin{tabular}{llll} 
& MILITARY & GENERAL & \multicolumn{2}{l}{ LIFETIME } \\
& INVENTIONS & INVENTIONS & INVENTIONS \\
\# Inventors & Before War & Civil War & Before War Civil War
\end{tabular}

$\begin{array}{lrlllll}\text { VETERANS } & 147 & 0.20 & 0.66 & 0.61 & 1.09 & 5.40 \\ \text { NONVETERANS } & 745 & 0.18 & 0.38 & 3.48 & 1.17 & 6.23 \\ \text { OCCUPATION } & & & & & & \\ \text { BEFORE WAR } & & & & & & \\ \text { Artisan } & 290 & 0.16 & 0.40 & 7.01 & 1.06 & 4.33 \\ \text { Farmer } & 124 & 0.16 & 0.19 & 0.53 & 0.73 & 3.07 \\ \text { Technical } & 172 & 0.24 & 0.49 & 1.62 & 1.52 & 9.12 \\ \text { Manufacturer } & 125 & 0.62 & 1.02 & 1.90 & 1.93 & 11.62 \\ \text { Professional } & 187 & 0.31 & 0.95 & 1.27 & 1.74 & 6.67 \\ \text { Trader/merchant } & 114 & 0.06 & 0.69 & 0.98 & 1.44 & 6.54 \\ \text { Laborer } & 113 & 0.10 & 0.40 & 0.54 & 0.88 & 4.39 \\ \text { None } & 53 & 0.02 & 0.26 & 0.40 & 0.96 & 6.19 \\ \text { Unknown } & 181 & 0.23 & 0.45 & 0.59 & 0.77 & 5.91\end{array}$

REGION OF BIRTH

New England $\quad 468$

Middle Atlantic $\quad 408$

East North Central 84

West North Central 7

South

101

Foreign

274

Unknown

17

0.32

0.61

0.60

5.30

0.89

1.43

7.21

0.19

0.41

0.58

1.31

6.04

0.04

0.43

0.43

0.95

5.92

0.43

0.41

0.71

3.86

0.16

0.73

0.73

4.64

0.24

0.50

0.63

1.11

5.76

0.71

0.59

8.12

REGION OF PATENTING

New England $\quad 415$

Middle Atlantic $\quad 458$

East North Central 256

$0.30 \quad 0.60$

5.67

1.41

6.62

0.21

0.67

1.11

1.38

6.61

West North Central 50

0.12

0.31

0.62

0.98

4.73

0.02

0.34

0.12

0.76

3.80

South

115

0.32

0.60

0.91

1.02

5.09

0.03

0.29

0.14

0.71

5.21

Other

17

0.06

0.30

0.06

0.42

2.76

Unknown

20

0.65

1.10

0.75

1.50

6.25

ALL INVENTORS 1359

0.22

0.55

2.32

1.27

6.29 
Table 4

GEOGRAPHICAL MOBILITY AMONG U.S. POPULATION AND INVENTORS

\section{MIGRATION BETWEEN 1860 AND 1870}

\begin{tabular}{|c|c|c|c|c|c|c|c|c|c|c|c|c|c|}
\hline RESIDENCE IN 1860 & U.S. PC & $\begin{array}{l}\text { Migran } \\
\text { row \% }\end{array}$ & $\begin{array}{l}\mathrm{t}=1 \\
\mathrm{col} \%\end{array}$ & \multicolumn{2}{|c|}{$\begin{array}{l}\text { MILITARY } \\
\text { INVENTORS }\end{array}$} & $\begin{array}{l}\mathrm{t}=1 \\
\mathrm{col} \%\end{array}$ & \multicolumn{3}{|c|}{ ALL INVENTORS } & \multicolumn{2}{|c|}{$\begin{array}{l}\text { MILITARY } \\
\text { INVENTORS }\end{array}$} & $\begin{array}{l}\text { Migran } \\
\text { row\% }\end{array}$ & $\begin{array}{l}\mathrm{t}=1 \\
\mathrm{col} \%\end{array}$ \\
\hline East North Central & $\begin{array}{l}25.1 \% \\
\mathrm{~N}=430\end{array}$ & 19.8 & 32.2 & $\begin{array}{l}12.4 \% \\
48\end{array}$ & 22.9 & 18.0 & $\begin{array}{l}19.7 \% \\
191\end{array}$ & 13.6 & 18.4 & 93.8 & 18.5 & 82.7 & 26.9 \\
\hline Middle Atlantic & $\begin{array}{l}25.2 \% \\
\mathrm{~N}=432\end{array}$ & 11.4 & 18.6 & $\begin{array}{l}35.5 \% \\
137\end{array}$ & 11.0 & 24.6 & $31.7 \%$ & 11.4 & 24.8 & 56.2 & 31.7 & 51.8 & 27.0 \\
\hline New England & $\begin{array}{l}14.4 \% \\
N=246\end{array}$ & 13.4 & 12.5 & $\begin{array}{l}36.5 \% \\
141\end{array}$ & 14.2 & 32.8 & $\begin{array}{l}34.0 \% \\
329\end{array}$ & 14.9 & 34.8 & 49.7 & 28.8 & 48.6 & 27.2 \\
\hline South & $\begin{array}{l}25.5 \% \\
N=436\end{array}$ & 13.4 & 22.2 & $\begin{array}{l}10.4 \% \\
40\end{array}$ & 25.0 & 16.4 & $\begin{array}{l}9.2 \% \\
89\end{array}$ & 21.4 & 13.5 & 77.5 & 12.8 & 66.3 & 10.0 \\
\hline West & $\begin{array}{l}2.0 \% \\
\mathrm{~N}=35\end{array}$ & 27.9 & 3.7 & $\begin{array}{l}2.3 \% \\
9\end{array}$ & 33.3 & 4.9 & $\begin{array}{l}1.9 \% \\
18\end{array}$ & 22.2 & 2.8 & 100.0 & 3.7 & 100.0 & 3.1 \\
\hline West North Central & $\begin{array}{l}7.8 \% \\
N=133\end{array}$ & 21.6 & 10.9 & $\begin{array}{l}2.8 \% \\
11\end{array}$ & 18.2 & 3.3 & $\begin{array}{l}3.6 \% \\
35\end{array}$ & 22.9 & 5.7 & 100.0 & 4.5 & 97.1 & 5.8 \\
\hline $\begin{array}{l}\text { TOTAL PCT } \\
\text { TOTAL N }\end{array}$ & $\begin{array}{l}100 \% \\
1711\end{array}$ & $\begin{array}{l}--- \\
---\end{array}$ & $\begin{array}{l}15.4 \% \\
264\end{array}$ & $\begin{array}{l}100 \% \\
386\end{array}$ & --- & $\begin{array}{l}15.8 \% \\
61\end{array}$ & $\begin{array}{l}100 \% \\
969\end{array}$ & --- & $\begin{array}{l}14.6 \% \\
141\end{array}$ & $\begin{array}{l}--- \\
386\end{array}$ & $\begin{array}{l}63.0 \\
243\end{array}$ & $\begin{array}{l}--- \\
969\end{array}$ & $\begin{array}{l}60.7 \% \\
588\end{array}$ \\
\hline $\begin{array}{l}\text { NATIVE BORN ONLY } \\
\text { TOTAL PCT } \\
\text { TOTAL N }\end{array}$ & $\begin{array}{l}Y \\
100 \% \\
1711\end{array}$ & --- & $\begin{array}{l}15.4 \% \\
264\end{array}$ & $\begin{array}{l}100 \% \\
307\end{array}$ & --- & $\begin{array}{l}16.6 \% \\
51\end{array}$ & $\begin{array}{l}100 \% \\
790\end{array}$ & $\begin{array}{l}--- \\
---\end{array}$ & $\begin{array}{l}14.9 \% \\
118\end{array}$ & $\begin{array}{l}--- \\
307\end{array}$ & $\begin{array}{l}53.4 \% \\
164\end{array}$ & $\begin{array}{l}--- \\
790\end{array}$ & $\begin{array}{l}52.8 \% \\
409\end{array}$ \\
\hline
\end{tabular}

\section{LIFETIME MIGRATION THROUGH 1870}


Table 5

OCCUPATIONAL MOBILITY AMONG U.S. POPULATION AND INVENTORS BETWEEN1860 AND 1870

(percent of 1860 occupational class in 1870 occupational class)

OCCUPATIONS

in 1860 and 1870

Commercial, commercial

Commercial, farmer

Commercial, skilled

Commercial, white collar

Commercial, worker

$\mathrm{N}(1860,1870)=$

Farmer, commercial

Farmer, farmer

Farmer, skilled

Farmer, white collar

Farmer, worker

$\mathrm{N}(1860,1870)=$

Skilled, commercial

Skilled, farmer

Skilled, skilled

Skilled, white collar

Skilled, worker

$\mathrm{N}(1860,1870)=$

White collar, commercial

White collar, farmer

White collar, skilled

White collar, white collar

White collar, worker

$\mathrm{N}(1860,1870)=$

Worker, commercial

Worker, farmer

Worker, skilled

Worker, white collar

Worker, worker

$\mathrm{N}(1860,1870)=$

TOTAL

\author{
U.S. POPULATION ALL INVENTORS
}

72.4

3.8

10.8

10.8

2.2

$(185,257)$

19.8

60.4

9.4

3.8

6.6

$(106,104)$

19.6

4.2

61.9

9.3

5.0

$(378,299)$

11.1

2.2

9.6

73.3

3.7

$(135,165)$

14.4

15.6

24.4

7.8

37.8

$(90,69)$

894

\section{MILITARY INVENTORS}

76.5

6.2

6.2

11.1

0.0

$(81,110)$

20.8

58.3

8.3

8.3

4.2

$(24,27)$

18.2

2.6

68.2

8.4

2.6

$(154,124)$

9.9

2.5

8.6

77.8

1.2

$(81,89)$

24.2

6.9

17.2

6.9

44.8

$(29,19)$

369

NOTES: Commercial includes traders, merchants and manufacturers; skilled includes machinists, engineers, artisans, and mechanics; white collar includes professionals such as physicians and book keepers; workers include farm labourers and unskilled individuals. The data set here includes only those individuals for whom information on jobs was available in both years, and excludes those who had no occupation or who were not located in one of the years. The percentages refer to the percent within the first-mentioned occupational class (commercial, farmers, skilled, white collar and workers) in 1860 that fell within the adjacent class in 1870. The Ferrie sample for the U.S. population includes only white native-born adult males (letters A through C) who were linked in both years, and the weights adjust the Ferrie sample observations to the national proportions for birthplace, region and occupation. The sample of inventors is unweighted. 
TABLE 6 :NEGATIVE BINOMIAL REGRESSIONS OF MILITARY PATENTING AMONG INVENTORS, 1855-1870

\begin{tabular}{|c|c|c|c|c|}
\hline \multirow{3}{*}{ Intercept } & \multicolumn{2}{|c|}{ MILITARY PATENTS DURING WAR } & \multicolumn{2}{|c|}{ TOTAL MILITARY PATENTS } \\
\hline & $-3.66 * * *$ & $4.04^{* * *}$ & $-1.30 *$ & $-.85^{*}$ \\
\hline & $(23.1)$ & $(19.0)$ & $(4.17)$ & (4.99) \\
\hline \multirow[t]{2}{*}{ Age } & 0.05 & 0.06 & -0.04 & $0.06^{*}$ \\
\hline & $(2.52)$ & $(2.78)$ & $(2.65)$ & (3.53) \\
\hline \multirow[t]{2}{*}{ Age squared } & -0.00 & -0.00 & -0.00 & -0.00 \\
\hline & $(0.00)$ & $(1.65)$ & $(1.71)$ & $(2.36)$ \\
\hline \multicolumn{5}{|l|}{ REGION } \\
\hline \multirow[t]{2}{*}{ Midwest } & 0.08 & 0.02 & 0.34 & 0.23 \\
\hline & $(1.25)$ & $(0.00)$ & $(0.68)$ & $(0.24)$ \\
\hline \multirow{2}{*}{ Middle Atlanti } & 0.26 & 0.15 & 0.58 & 0.47 \\
\hline & $(0.40)$ & $(0.11)$ & $(2.42)$ & $(1.00)$ \\
\hline \multirow[t]{2}{*}{ New England } & 0.18 & 0.07 & $0.67 *$ & 0.59 \\
\hline & $(0.18)$ & $(0.03)$ & (3.19) & $(1.54)$ \\
\hline \multirow[t]{2}{*}{ South } & 0.63 & 0.45 & $0.81 *$ & 0.65 \\
\hline & $(2.04)$ & $(0.85)$ & $(4.28)$ & $(1.71)$ \\
\hline \multicolumn{5}{|c|}{ OCCUPATION } \\
\hline \multirow[t]{2}{*}{ Technical } & -0.17 & -0.07 & 0.07 & 0.18 \\
\hline & $(1.16)$ & $(0.18)$ & $(0.27)$ & $(1.41)$ \\
\hline \multirow[t]{2}{*}{ Trader } & 0.10 & 0.17 & $0.43^{* * *}$ & $0.53 * * *$ \\
\hline & $(0.40)$ & $(0.89)$ & $(7.98)$ & (10.14) \\
\hline \multirow[t]{2}{*}{ Manufacturer } & $0.36^{* *}$ & $0.44^{* * *}$ & $0.38 * * *$ & $0.49 * * *$ \\
\hline & (5.18) & $(6.23)$ & (6.97) & $(8.38)$ \\
\hline \multirow[t]{2}{*}{ Professional } & $0.60 * * *$ & $0.59 * * *$ & $0.60 * * *$ & $0.65 * * *$ \\
\hline & (19.75) & (14.56) & $(22.0)$ & (19.98) \\
\hline \multirow[t]{2}{*}{ Farmer } & -0.43 & -0.40 & -0.30 & -0.31 \\
\hline & (3.00) & $(2.48)$ & $(2.17)$ & $(2.07)$ \\
\hline \multicolumn{5}{|l|}{ MOBILITY } \\
\hline \multirow[t]{2}{*}{ Migrant } & 0.04 & -0.03 & 0.09 & -0.02 \\
\hline & $(0.14)$ & $(0.07)$ & $(0.87)$ & $(0.05)$ \\
\hline Occupational & $-0.25 * * *$ & -0.18 & $-0.29 * * *$ & $-0.22 * *$ \\
\hline & $(6.29)$ & $(3.00)$ & $(10.83)$ & $(4.89)$ \\
\hline \multicolumn{5}{|c|}{ URBANIZATION } \\
\hline \multirow[t]{2}{*}{ Rural } & $-0.73 * * *$ & $-0.66 * * *$ & $-0.45 * * *$ & -0.26 \\
\hline & (14.31) & $(9.97)$ & $(7.62)$ & (3.74) \\
\hline Urban & $-0.52 * * *$ & $-0.48 * * *$ & $-0.25 * * *$ & $-0.18 *$ \\
\hline & (24.03) & $(16.72)$ & $(6.82)$ & $(2.75)$ \\
\hline TIME PERIOD & & & & \\
\hline Antebellum & $0.73 * * *$ & $0.88 * * *$ & $-0.41 * * *$ & -0.36 \\
\hline & $(9.88)$ & $(10.5)$ & $(5.32)$ & (3.17) \\
\hline Civil War & $2.02 * * *$ & $2.14 * * *$ & $0.41 * * *$ & $0.51^{* * *}$ \\
\hline & (145.9) & (104.55) & $(16.15)$ & (17.04) \\
\hline MILITARY OR & IENTATIC & & & \\
\hline Log (Career & $0.53^{* * *}$ & $0.50^{* * *}$ & $0.64^{* * *}$ & $0.62 * * *$ \\
\hline Patents) & (109.51) & $(75.82)$ & (209.18) & (148.21) \\
\hline Log (Prewar & $--0.10 * * *$ & $--0.10 * * *$ & $-0.14 * * *$ & $-0.14 * * x$ \\
\hline Patents ） & (19.47) & (15.07) & (39.19) & (29.86) \\
\hline Log (Military & $0.16 * * *$ & $0.15^{* * *}$ & $0.40^{* * *}$ & $0.41^{* * *}$ \\
\hline Pats before war & $(24.25)$ & (18.28) & (162.93) & (131.0) \\
\hline WEALTH & & & & \\
\hline Poor & ------- & 0.11 & ------- & $0.31^{* * *}$ \\
\hline & & $(0.68)$ & & $(6.16)$ \\
\hline Wealthy & -------- & 0.13 & ------- & 0.08 \\
\hline & & $(0.88)$ & & $(0.32)$ \\
\hline
\end{tabular}


Notes and Sources: See text and notes to previous tables for sources. Negative binomial regressions are linear exponential models that are applied to dependent variables that comprise nonnegative integer counts. This model allows for a distribution that is left-skewed because of zero values in the dependent variable. The negative binomial model belongs to the class of generalized Poisson models, but allows for overdispersion or instances where mean counts differ from their variance. The model was estimated using maximum likelihood methods. The estimated coefficients are interpreted as percentage changes in the dependent variable given a unit change in the independent variable. Absolute values of Chi-square statistics are in the parentheses. Alternative models, including logistic and OLS regressions, yielded essentially the same results. Urban is a dummy variable for counties with populations between 25000 and 50000 and rural refers to counties with populations below 25000. Military patents are granted for weapons and war-related inventions such as tents and knapsacks. Poor is a dummy variable for inventors with less than $\$ 100$ in total wealth and wealthy represents those with over \$5000 in total wealth. The excluded regional variable is the West and foreign and the time period is relative to the postwar period. Career patents are the total patents filed over the inventor's entire lifetime. 
Table 7

DISTRIBUTION OF INVENTORS’ WEALTH IN 1860 AND 1870 BY MILITARY ORIENTATION (column percent)

REAL ESTATE

\begin{tabular}{lllllll} 
& \multicolumn{2}{c}{ General Inventors } & \multicolumn{3}{c}{ Military Inventors } & All Inventors \\
\cline { 2 - 8 } & 1860 & 1870 & 1860 & 1870 & 1860 & 1870 \\
None & 51.6 & 40.9 & 57.1 & 45.3 & 54.0 & 42.7 \\
\$1-\$499 & 3.1 & 3.4 & 3.4 & 2.1 & 3.2 & 2.8 \\
\$500-\$999 & 5.2 & 6.2 & 2.5 & 3.7 & 4.0 & 5.2 \\
\$1000-\$1999 & 11.9 & 10.2 & 9.9 & 9.2 & 11.0 & 9.8 \\
\$2000-\$4999 & 13.5 & 18.1 & 7.8 & 13.8 & 11.0 & 16.4 \\
\$5000-\$9999 & 8.0 & 8.8 & 8.4 & 9.7 & 8.2 & 9.2 \\
\$10000 and above & 6.8 & 12.3 & 10.9 & 16.3 & 8.6 & 13.9 \\
& & & & & & \\
AVERAGE & 4158 & 5710 & 7552 & 8716 & 5641 & 6908 \\
MEDIAN & 0 & 993 & 0 & 709 & 0 & 922 \\
STD DEV & 40000 & 22501 & 31195 & 28249 & 36438 & 24980 \\
N= & 616 & 657 & 493 & 435 & 1012 & 1092
\end{tabular}

PERSONAL WEALTH

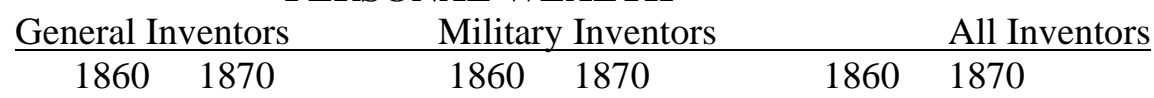

$\begin{array}{lllllll}\text { None } & 32.9 & 26.2 & 40.1 & 31.3 & 36.0 & 28.3 \\ \text { \$1-\$499 } & 31.3 & 25.5 & 22.4 & 18.2 & 27.5 & 28.3 \\ \text { \$500-\$999 } & 5.4 & 13.4 & 6.2 & 12.7 & 5.7 & 13.1 \\ \text { \$1000-\$1999 } & 12.5 & 8.8 & 12.0 & 10.6 & 12.3 & 9.5 \\ \begin{array}{l}\text { \$2000-\$4999 } \\ \text { \$5000-\$9999 }\end{array} & 8.0 & 12.7 & 7.1 & 11.7 & 7.6 & 12.3 \\ \text { \$10000 and above } & 6.2 & 4.1 & 3.0 & 3.5 & 4.8 & 3.9 \\ & & 9.3 & 9.2 & 12.0 & 6.1 & 10.4 \\ \text { AVERAGE } & 1948 & 4316 & 4063 & 6246 & 2873 & 5019 \\ \text { MEDIAN } & 300 & 426 & 300 & 567 & 300 & 447 \\ \text { STD DEV } & 6558 & 20215 & 16276 & 22268 & 11871 & 21067 \\ \text { N= } & 578 & 656 & 493 & 434 & 1012 & 1090\end{array}$

AVERAGE WEALTH OF MALE POPULATION AND WAR INVENTORS IN 1860 AND 1870 REAL ESTATE WEALTH PERSONAL WEALTH

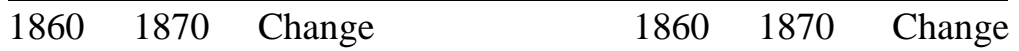

INVENTORS RESPONSIVE TO WAR

$\begin{array}{lllllll}\begin{array}{l}\text { First military invention } \\ \text { Filed during war }\end{array} & 8859 & 8508 & -287 & 4071 & 5954 & 1630 \\ \begin{array}{l}\text { First invention } \\ \text { Filed during war }\end{array} & 4112 & 5490 & 2850 & 2576 & 3595 & 1558 \\ & & & & & & \\ \text { US POP (Soltow) } & 2231 & 2141 & --- & 1549 & 966 & -- \\ \text { US POP SAMPLE } & 1521 & 1712 & 734 & 892 & 880 & -13 \\ \text { MEDIAN } & 0 & 709 & 0 & 200 & 355 & 55 \\ \text { S.D. } & 3768 & 6864 & 6605 & 2844 & 2796 & 3414\end{array}$

Notes: The computations exclude observations with missing values in either year. Wealth in 1870 is deflated by 1.41 to obtain real values. 
TABLE 8: OLS REGRESSIONS OF LOG OF PERSONAL WEALTH IN 1870 AMONG NATIVE-BORN POPULATION AND INVENTORS

$\begin{array}{ll}\text { Intercept } & 0.19 \\ & (0.26) \\ \text { Age } & 0.15 \\ & (4.41)\end{array}$

Age squared $\quad-0.002$

(4.56)

Log(personal $\quad 0.25$

wealth in 1860) (8.41)

REGIONS

Midwest

1.05

(2.19)

Middle Atlantic 0.95

(1.92)

New England 0.93

(1.84)

South

0.52

(1.07)

OCCUPATIONS

Technical $\quad 0.13$

(0.20)

Trader $\quad 1.22$

(3.95)

Manufacturer $\quad-1.09$

(1.44)

Professional $\quad 0.74$

$$
\text { (2.51) }
$$

Farmer

0.54

MOBILITY

(3.06)

Migrant

0.02

(0.13)

Occupational 0.14

Persistence (0.95)

URBANIZATION

Rural

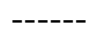

Urban

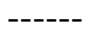

CAREER PATENTS

Log (Stock of patents before war)

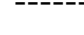

$(0.82)$

1.36

(3.26)

1.63

(3.85)

0.04

$(0.11)$

0.39

(0.99)

$-0.30$

(1.16)

0.39

(1.63)
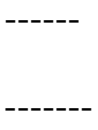

Log (Stock of patents during war)

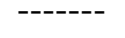

INVENTORS

0.56

(0.35)

0.14

(2.17)

$-0.002$

(2.31)

0.21

(5.13)

0.06

(0.07)

0.10

(0.11)

0.37

(0.38)

$-0.14$

(0.14)

0.37

(1.02)

1.47

(1.47)

1.60

(3.79)

0.16

(0.43)

0.35

(0.90)

$-0.23$

(0.88)

0.46

(1.90)

0.86

(2.10)

1.22

(4.23)
1.46

(0.87)

0.13

(1.90)

$-0.002$

(2.11)

0.20

(4.82)

0.15

(0.15)

0.21

(0.22)

0.49

(0.50)

0.02

((0.02)

0.33

(0.89)

1.47

(3.52)

1.56

(0.86)

0.19

(0.50)

0.34

(0.86)

$-0.15$

(0.59)

0.41

(1.69)

0.93

(2.25)

1.25

(4.31)

0.19

(1.93)

0.03

(0.38)

$-1.86$

(2.97)

$-0.48$

(1.03)

0.25

(0.47)

0.44

(0.86) 


\begin{tabular}{|c|c|c|c|c|}
\hline Adjusted $\mathrm{R}^{2}$ & 0.17 & 0.08 & 0.10 & 0.11 \\
\hline F-Stat & 26.39 & 6.70 & 7.46 & 5.91 \\
\hline $\mathrm{N}$ & 1711 & 923 & 898 & 896 \\
\hline
\end{tabular}

Notes and Sources: See text and notes to previous tables for sources. Absolute value of t-statistics are in parentheses. All the F-statistics are significant at the .01 percent level. The dependent variable refers to the log of reported personal wealth plus one dollar. Urban is a dummy variable for counties with populations between 25000 and 50000 and rural refers to counties with populations below 25000 . 